\title{
Risywah Dalam Tinjauan Hukum Islam dan Undang-Undang Tindak Pidana Suap*
}

\author{
(RISYWAH IN ISLAMIC LAW REVIEW \\ AND THE LAW ON THE CRIME OF BRIBERY)
}

\author{
Bahgia \\ FAI Universitas Ibn Khaldun Bogor \\ Jl. KH. Sholeh Iskandar \\ E-mail: bahgia@yahoo.com
}

\begin{abstract}
The behavior of consuming illicit wealth by way of bribes (rasywah) is already entrenched in the middle of the Indonesian people and the world community in general. That is why since the beginning of Islam came Messenger of Allah has warned Muslims to acquire wealth through legal means. Accepting bribes or kickbacks is a very nasty behavior, because there are hidden fraudulent behavior committed to achieve a certain goal. In Indonesia bribery act categorized as acts of corruption punishable by imprisonment.
\end{abstract}

Keywords: risywah, Islamic Law, Law

\begin{abstract}
Abstrak: Perilaku memakan harta haram dengan cara suap (rasywah) memang sudah sangat mengakar di tengah-tengah masyarakat Indonesia, dan masyarakat dunia secara umum. Itulah sebabnya sejak awal Islam datang Rasulullah telah mengingatkan kepada umat Islam untuk memperoleh harta dengan cara yang halal, tanpa mendzalimi orang lain. Menerima suap atau memberi suap merupakan perilaku yang sangat keji, karena ada perilaku curang yang diterselubung yang dilakukan untuk mencapai suatu tujuan tertentu. Di Indonesia perbuatan suap dikategorikan sebagai perbuatan korupsi yang diancam dengan hukuman penjara.

Kata Kunci: Risywah, Hukum Islam, Undang-undang
\end{abstract}

* Diterima tanggal naskah diterima: 22 Juli 2013, direvisi: 25 September 2013, disetujui untuk terbit: 3 November 2013. 


\section{Pendahuluan}

Fenomena semakin meningkatnya kebutuhan hidup manusia dewasa ini menjadikan banyak orang melakukan berbagai bentuk tingkah laku untuk memenuhinya. Keterdesakan yang mengungkung seseorang tidak jarang memaksa orang yang bersangkutan untuk melakukan segala cara dan menghalalkan berbagai bentuk. Hal itu ditandai dengan maraknya kasus pungutan liar yang meramaikan daftar pemberitaan media setiap harinya. Di sisi lain, mereka yang menginginkan urusannya menjadi lebih cepat, lebih lancar dan dapat dituntaskan sesuai keinginan, tidak segan-segan untuk membayarkan sejumlah bayaran kepada pihak yang memiliki kewenangan menyelesaikan urusan yang dimaksud. Bentuk-bentuk perilaku kotor yang kerap kali terjadi di tengah-tengah masyarakat ini kian hari kian menimbulkan dampak yang semakin memburuk.

Salah satu dari dampak yang sangat penting untuk dijadikan renungan adalah menurunnya tingkat kepercayaan masyarakat terhadap para pelaku dan lembaga yang mengelola urusan umum, baik bersifat swasta maupun pemerintah. Maka oleh sebab terbentuknya image buruk tersebut terjadilah ketimpangan dalam setiap urusan kehidupan. Satu dari sekian perilaku buruk pengelola urusan masyarakat yang sudah menjadi rahasia umum adalah sikap menerima uang, barang, tips atau apapun namanya dengan tujuan memuluskan suatu urusan di luar prosedur yang telah di tetapkan. Tanpa melihat bagaimana dampak terhadap masyarakat dan bangsa.

Perilaku seperti ini sering di istilahkan dengan "risywah" atau dalam terminologi masyarakat negeri ini disebut sebagai "suap". Suap menjadi suatu rahasia umum yang telah melegalkan banyak hal, yang dulunya dianggap tabu. Suap berubah menjadi suatu kecenderungan hidup yang dapat menghancurkan nilai-nilai dan norma-norma kehidupan.

Banyak interpretasi tentang suap yang cenderung lari dari kebenaran, karena candu-candu paradigma meterialisme telah membudaya dalam umat ini. Segala sesuatu dilakukan demi kepentingan pribadi dan urusan duniawi, sehingga suap yang jelas-jelas haram di ubah kemasannya menjadi layaknya sebuah hadiah. Orang yang menerimapun dengan senang hati mengambil apa yang diberikan, meskipun telah di sebutkan dalil yang menunjukkan haram dan dosa bagi pelakunya. 
Sejak dulu Nabi Muhammad saw sudah mengingatkan bahwa penyakit ini menyebabkan rusaknya tatanan dan moral masyarakat, sehingga terjadi ketimpangan dalam umat. Syetan telah menggoda manusia dengan mencampuradukkan antara yang haq dengan yang batil, serta menjurumuskannya ke jalan kesesatan. Syetan selalu menghantui pikiran manusia, sehingga akhirnya ia menganggap bahwa suap merupakan bagian dari hadiah. ${ }^{1}$ Sesungguhnya yang halal telah jelas dan yang haram telah jelas. (HR. Bukhari). ${ }^{2}$

Makna ucapan "Al Halaalu Bayyin wal Haraamu Baynun “. Imam AnNawawi berkata, segala sesuatu terbagi atas tiga bagian; Halal itu jelas dan tidak diragukan kehalalannya seperti roti dan buah-buahan serta jenis makanan-makanan yang lainnya. Semuanya mengandung unsur halal yang jelas tak ada keraguan di dalamnya. Adapun yang haram juga jelas, seperti khamar, babi, bangkai, darah, begitu juga hukum zina, berbohong, ghibah, tamimah yang di tujukan kepada orang lain dan yang serupa dengannya. Sedangkan syubhat tidak ada kejelasan yang pasti antara halal dan haram.

Berdasarkan survey yang dilakukan oleh PERC (political \& Economic Risk Consultancy) yang berbasis di Hongkong, dalam survey persepsi korupsi 2011 terhadap perilaku bisnis, Indonesia menjadi negara paling korup dari 16 negara di kawasan Asia Pasifik. ${ }^{3}$ Sejak 2004 jumlah laporan soal gratifikasi terus meningkat hingga 2011. Namun angkanya sempat turun pada 2012. Untuk 2010 ada 349 laporan, 2011 sebanyak 1.373 laporan, dan 2012 sebanyak 1.158 laporan. ${ }^{4}$ Hal yang menunjukkan semakin buruknya indeks korupsi Indonesia juga di pertegas dengan rangking Indonesia yang semakin meningkat, di mana berdasarkan rilis Transparancy Internasional indeks tingkat korupsi di Indonesia naik dari peringkat 100 menjadi 118 pada $2012 .{ }^{5}$

Melalui data ini, setidaknya kita dapat memotret realita kehidupan negeri ini, di mana kasus suap kian hari, kian menjadi tren yang semakin diminati oleh masyarakat yang tidak memiliki batas kepuasan terhadap harta

1. Abdul Ghani bin Ismail An-Nablusi, Hukum Suap dan Hadiah, Jakarta: Maktabah AlQur'an, 2003, hlm.11

2. Muhammad bin Ismail Abu 'abdillah, Shahih Bukhari, versi maktabah syamilah, Bab halal itu jelas dan haram itu jelas, Juz 3,hlm.53

3. Survey PERC; Indonesia Negara Terkorup di Asia Pasifik, http;//nasional.kompas.com di akses 09/04/2014 pukul.06.00

${ }^{4}$. KPK akan selidiki Suap Berupa Iming-iming Seks, www.tempo.co

5. Corruption perceptions indeks 2012, http;//www.transparancy.org 
yang mereka miliki. Kasus suap ini tidak hanya menjadi masalah di tingkat pemegang kebijakan saja, baik legislatif, yudikatif dan eksekutif. Akan tetapi kasus suap ini sudah menjadi budaya yang menjalar ke setiap segmen kehidupan masyarakat. Meskipun di tingkat pemegang kebijakan, telah di bentuk Undang-undang tindak pidana suap No.11 tahun 1980, bahkan di bentuk pula lembaga khusus bernama KPK (Komisi Pemberantas Korupsi), namun kasus suap ini nampaknya belum dapat ditaklukkan, karena bahkan sebagian dari pengelola kebijakan Negara ini bertekuk lutut di hadapan virus yang bernama suap ini.

Dari beberapa kasus suap yang pernah ditangani oleh Komisi Peberantas Korupsi (KPK), dapat diamati bahwa materi yang digunakan oleh pihak pemberi suap tidak hanya berupa uang saja. Selain memberi uang untuk masalah-masalah yang bernilai besar, para pelaku suap tidak jarang menggunakan wanita dalam setiap modus operadinya. Suap dengan menggunakan jasa wanita ini sering disebut sebagai "gratifikasi seksual". Sekalipun secara undang-undang gratifikasi seperti ini belum ada rumusan rincinya, akan tetapi Alquran dan al-Sunnah memiliki konsep yang lebih paripurna terkait dengan risywah ini.

Perilaku memakan harta haram dengan cara risywah ini memang sudah sangat mengakar di tengah-tengah masyarakat negeri ini, dan masyarakat dunia secara umum. Itulah sebabnya sejak awal Islam datang Rasulullah saw telah menjelaskan masalah cara memperoleh harta ini.

"Dari Abu Hurairah ra, Rasulullah saw bersabda, "akan datang kepada manusia suatu zaman, seseorang tidak peduli lagi dari mana ia mendapatkan hartanya, apakah dari jalan yang halal atau haram". (HR.Bukhari dan anNasai). ${ }^{6}$

Di antara bentuk muamalah yang mengandung kezhaliman terhadap orang banyak adalah suap. ${ }^{7}$ Dia termasuk dosa besar paling berbahaya yang dapat menimbulkan kehancuran ekonomi, politik, sekaligus sosial. Suap menjadi bukti nyata lemahnya komitmen beragama dan merajalelanya kerusakan moral dan penyewelengan perilaku dalam suatu masyarakat.

\footnotetext{
6. Shahih Bukhari,maktabah syamilah, hlm.591

7. Erwanditarmizi, Harta Haram Muamalat Kontemporer, Bogor : P.T. Berkat Mulia Insani, Cetakan ke-4, 2013,hlm.190.
} 
Dewasa ini budaya suap telah menggurita di seluruh aspek dan lini kehidupan manusia. ${ }^{8}$

Untuk memperkuat dari steatment diatas di latar belakang masalah ini akan dinukilkan beberapa fakta dari berbagai media masa yang insya Allah bisa dipertanggungjawabkan dan independent dalam pemberitaan berkaitan dengan tindak suap-menyuap dan korupsi di negeri ini.

\section{Suap Menyuap Di Lembaga DPR ${ }^{9}$}

Terungkapnya kasus korupsi M. Nazaruddin, anggota DPR-RI yang menyeret sejumlah anggota DPR lainnya kembali mempertontonkan kepada rakyat bahwa suap-menyuap atau korupsi sangat berpotensi terjadi di lembaga negara seperti DPR, DPRD Provinsi dan DPRD Kabupaten/Kota. Kasus ini menjadi "semakin ramai" karena selama pelariannya di luar negeri Nazaruddin menyebutkan sejumlah nama lain seperti Menteri Pemuda dan Olah Raga Andy Mallarangeng serta Ketua Umum Partai Demokrat Anas Urbaningrum yang juga mendapatkan bagian lumayan besar. Tentu saja, ocehan Nazar itu menjadi pukulan berat- terutama Partai Demokrat yang memenangkan Pemilu 2009 lalu dengan semboyan " katakan tidak untuk korupsi".

Pasalnya, kasus yang telah mengisi opini publik itu memberitahu bahwa korupsi bisa muncul di lembaga terhormat itu karena inisiatif anggotanya. Kasus Nazaruddin juga menunjukkan adanya mata rantai yang luas dan berpotensi terjadi karena langkah politik. Dari pemeriksaan dua orang terdakwa kasus tersebut di Pengadilan Tipikor Jakarta (Rosa Manulang dan Idris) terungkap bahwa proses penyuapan sudah diskenariokan sejak awal. Sudah ada yang mengatur pembagian dan juga persentase pembagian.

Sudah pasti, kasus Nazaruddin membuat kepercayaan rakyat terhadap wakilnya di legislatif yang memang sudah menurun itu semakin tidak popular. Banyaknya kasus korupsi (suap menyuap) yang menyeret anggota DPR, seperti kasus cek pelawat pemilihan Deputi Senior (DGS) Bank Indonesia Miranda Gultom yang menginapkan sejumlah anggota DPR di lembaga pemasyarakatan, kemudian kasus dua orang anggota DPR secara

\footnotetext{
8. Husain Husain Syahatah, Suap dan Korupsi dalam perspektif syari'ah, Jakarta :ahmzah,2008,hlm.xi

9. http://www.lampung-news.com di akses pada hari Jumat, 26/ 08/ 2011, 16:13 MT+7.
} 
eksplisit mengaku menerima amplop (berisi 1000 dolar) dalam rangka pembahasan divestasi Bank Niaga.

Selanjutnya, kasus Menteri Kelautan dan Perikanan Rokhmin Dahuri terkait dana non bujeter yang disebut-sebut Rokhmin diberikan kepada sejumlah anggota DPR untuk memuluskan pembahasan UU Kelautan, dan yang paling "top" adalah kasus bailout (pemberian dana talangan) sebesar Rp 6,7 triliun kepada Bank Century, dua tahun lalu yang juga melibatkan salah seorang anggota DPR yang dikenal cukup vokal saat membahas permasalahan ini di DPR. Selain itu, kasus lain yang juga cukup ramai adalah pembengkakan (mark up) nilai proyek-proyek perintis Kementerian Perhubungan tahun 2009 lalu yang juga melibatkan salah seorang anggota DPR dari wilayah Sulawesi.

Dalam kasus ini si anggota dewan meminta "bagian" dari jumlah yang telah digelembungkan dalam anggaran proyek tersebut. Masih banyak kasus lainnya yang memberikan gambaran kepada publik bahwa potensi korupsi di lembaga ini sangat perlu diwaspadai dan sudah membahayakan kelangsungan hidup berbangsa dan bernegara.

Modusnya, pada rapat-rapat yang menentukan besaran anggaran untuk suatu kementerian misalnya, dalam hal perumusan materi keputusan dan pengambilan keputusan mendapat perhitungan tersendiri. Hitungannya, tergantung seberapa besar pertarungan terhadap materi yang diperjuangkan. Tentu saja bagi organisasi (partai) yang memiliki bargaining yang lebih besar berpeluang pula mendapatkan jumlah yang lebih besar pula.

Yang juga menarik adalah manuver yang dibuat oleh anggota DPR untuk mengalihkan perhatian publik dengan memunculkan isu-isu "seksi" lainnya. Seperti adanya tanggapan DPR yang cukup gencar dengan korupsi Gayus HP Tambunan tahun lalu sehingga perhatian publik dan para pengamat terarah kesana. Sementara itu, perhatian atau sorotan terhadap pembahasan anggaran Kemenpora untuk Wisma Atlet SEA Games pada tahun 2010 tersebut sepertinya terkesampingkan. Kini publik bertanya, apakah masih ada isu besar lain yang dimunculkan untuk "meredam" kasus Nazaruddin?

Terkait dengan praktek suap-menyuap di lembaga dewan seperti tersebut di atas, publik mencemati bahwa hampir semua komisi-komisi di DPR dan juga di DPRD (daerah) memiliki potensi yang tidak sama. Karena itu di masyarakat sudah terbangun istilah "komisi basah" dan "Komisi Kering". 
Demikian pula, alasan dan dampak proses penyuapan memiliki banyak keragaman di luar kepentingan mendapatkan keuntungan finansial itu sendiri. Dari kasus Nazaruddin misalnya, ada yang mengatur pembagian untuk individu dan mungkin juga untuk partai. Ini menunjukkan bahwa "kejahatan" seperti itu bisa sekali digunakan menjadi salah satu sumber finansial partai.

Contoh lain yang juga sudah sering terdengar adalah kegiatan reses turun ke lapangan memeriksa sejumlah proyek telah dimanfaatkan juga oleh anggota Dewan meminta "amplop" kepada dinas/instansi yang diperiksa mereka. Beberapa waktu lalu misalnya pers di Lampung memberitakan juga adanya anggota DPRD Kota Bandarlampung meminta bantuan ke beberapa pengusaha untuk biaya studi banding. Sebelum itu ada juga rumors bahwa DPRD Provinsi Lampung menerima "amplop" dari eksekutif terkait program ruitslag GOR Saburai Bandarlampung dari pusat kota ke wilayah pinggir kota di Kemiling.

Di dunia bisnis, adalah merupakan hal yang lumrah untuk mengeluarkan dana atau transaction cost untuk melancarkan urusan. Biaya ini bagi sebuah perusahaan merupakan komponen biaya yang sudah umum pada proyek-proyek pembangunan pemerintah. Artinya jika transaction cost nya besar maka anggaran yang dikeluarkan negara juga besar. Padahal sebagian dari anggaran itu dibagi-bagi oleh pihak tertentu. Pengusaha tentunya tidak terlalu keberatan selama nilai keuntungannya tidak terlalu digerogoti. Bagaimana dengan Nazaruddin?

Melihat pengalaman yang sudah-sudah, "semangat" M.Nazaruddin yang disebut banyak pihak akan menguak kasus-kasus lain yang besar-besar, bukanlah sesuatu yang mudah, dan karena itu tak perlu banyak berharap. Mulai ada kecenderungannya kasus yang kini diproses KPK itu hanya akan berputar-putar seputar Nazaruddin dan anak buah perusahaannya saja. Upaya Nazaruddin untuk mengungkap kasusnya karena tidak mau sendiri menanggung akibat, kelihatannya juga menghadapi situasi yang tidak mudah. Bahkan berpeluang menjadi bumerang bagi dia, baik secara pribadi atau pun kelompok.

Juru bicara KPK Johan Budi mengatakan KPK kini sedang mengumpulkan bukti-bukti aliran dana suap seperti yang disebut-sebut Nazar, sebab yang ada saat ini barulah ocehan M.Nazaruddin saja. "Buktinya 
belum ada untuk melakukan pemanggilan terhadap sejumlah nama tersebut," katanya beberapa waktu lalu.

Dari semangat KPK tersebut, publik melihat bahwa lembaga ini sepertinya mencari jalan supaya masalah ini berjalan "lembut" . Juru bicara KPK pun memberikan tanggapan minim, supaya dampak negatifnya lebih ringan. Padahal, KPK sendiri sudah sangat jelas bahwa Indonesia sendiri saat ini termasuk negara yang berada di urutan atas dalam masalah korupsi.

Fakta-fakta diatas merupakan keterpurukan bangsa ini yang benarbenar telah menjadi kejahatan publik. Ternyata bukan hanya kaum laki-laki. Kaum wanitapun tidak mau ketinggalan melakukan perampokan harta rakyat secara terselubung ini. Ulah para pejabat tersebut merupakan bagian kecil yang terekspos oleh media masa. Ibarat gunung salju ditengah lautan. Kelihatannya dipermukaannya hanyalah sedikit namun apa yang tertutup oleh air adalah bongkahan yang begitu besar.

Tidak sekedar itu dewasa ini pun banyak orang untuk memasukkan anak ke sekolah saja sering main suap, apalagi menjadi pegawai negeri dan polisi seolah hal itu sudah sangat lumrah sekali. Maka dari itu jangan heran kalau sistem birokrasi di negeri ini bobrok dan carut-marut bagai benang kusut. Karena memang mentalitas rendahan tukang suap dan penerima suap hanya akan mengukuhkan sistem lingkaran setan yang hanya bekerja menumpuk uang demi kepentingan pribadi atau kelompok.

Disisi lain suap di pahami sebagai hadiah atas wujud apresiasi kedekatan dan kecintaan yang obyektif. Namun seringkali orang berbuat risywah dengan dalih memberi hadiah. Bahkan hari ini marak Hadiah kepada pegawai, khususnya pegawai pemerintah, atau gratifikasi. Gratifikasi adalah pemberian dalam arti luas, yakni meliputi pemberian uang, barang rabat (diskon), komisi, pinjaman tanpa bunga, tiket perjalanan, fasilitas penginapan, perjalanan wisata, pengobatan cuma-cuma, dan fasilitas lainnya.

Seringkali pula orang tidak faham dan tidak bisa membedakan antara risywah dengan hadiah. Memang salah satu langkah dan tipu daya setan adalah mengubah nama sesuatu yang haram dengan nama yang menggiurkan seperti riba dengan bunga, risywah dengan hadiah atau parcel, penzina dengan "Pekerja" seperti istilah PSK dll. Sehingga banyak yang melakukan risywah dengan dalih memberi hadiah. Memang kalau kita tidak hati-hati bisa terjebak karena bedanya memang sangat tipis. 
Suap memang perkara mentalitas rendahan yang menunjukkan hubbud dunya (cinta pada dunia) yang berlebihan. Bagaimana tidak demikian ketika suara keadilan menjadi padam gara-gara di sumpal dengan uang sogokan. Mulut-mulut yang suka berkoar-koarpun menjadi hening karena uang suap yang menggiurkan. Oleh karena itu masyarakat terutama kaum muslimin sangat perlu memahami masalah ini dari perspektif yang adil dan benar sehingga negeri ini benar-benar terbebas dari praktek risywah.

\section{Pengertian Risywah Menurut Islam}

Secara etimologi Risywah berasal dari bahasa Arab رشا- يرشو - رشوة yang berarti “ Menjulurkan kepala”.

Adapun pendapat Ulama adalah sebagai berikut :

Ibnu Mandzur ${ }^{10}$ menyebutkan perkataan Abul ‘Abbas

"Rusywah/Risywah diambil dari konteks anak burung/ayam yang menjulurkan kepalanya pada mulut induknya seraya meminta agar makanan yang berada di paruh induknya di suapkan untuknya.

Ibrahim Mustafa menyebutkan bahwa kalimat risywah berasal dari kata ${ }^{11}$ الرشاء yang bermakna: "Seutas tali atau tali ember dan semacamnya"

Adapun menurut terminologi adalah Apa-apa yang diberikan (baik uang maupun hadiah) untuk mendapatkan suatu manfaat atau segala pemberian yang bertujuan untuk mengukuhkan sesuatu yang batil dan membatilkan suatu yang haq. ${ }^{12}$

Sedangkan pendapat Ulama adalah sebagai berikut:

Ibnu Hajar al 'Asqolani di dalam kitabnya Fathul Bari menukil perkataan Ibnu al 'Arobi ketika menjelaskan tentang makna rasywah.13

"Risywah atau suap-menyuap yaitu suatu harta yang diberikan untuk membeli kehormatan/ kekuasaan bagi yang memilikinya guna menolong/ melegalkan sesuatu yang sebenarnya tidak halal".

10. Ibnu Mandzur ,Lisanul 'Arob, Dar al Shodir, Beirut, Cetakan I, Juz 14 ,hlm. 322.

11. Ibrohim Musthofa, dkk (Majma' Lughoh 'arobiyyah), al Mu'jam al Wasith, Daru al Dakwah, Juz 1 hlm.348.

12. Al Mu'jam al Wasith.hlm 148

13. Ibnu Hajar al A'sqolani , Fathul Bari, Dar al Ma'rifah, Beirut, Juz 5,1379 H, hlm. 221. 
Abdullah Ibn Abdul Muhsin mendefinisikan sebagai berikut :

Risywah ialah sesuatu yang diberikan kepada hakim atau orang yang mempunyai wewenang memutuskan sesuatu supaya orang yang memberi mendapatkan kepastian hukum atau mendapatkan keinginannya. ${ }^{14}$ Risywah juga dipahami oleh ulama sebagai pemberian sesuatu yang menjadi alat bujukan untuk mencapai tujuan tertentu..$^{15}$

Adapun menurut MUI : suap (risywah) adalah pemberian yang diberikan oleh seorang kepada orang lain (pejabat) dengan maksud meluluskan suatu perbuatan yang batil ( tidak benar menurut syariah) atau membatilkan perbuatan yang hak. ${ }^{16}$ Jadi dari berbagai definisi diatas dapat di simpulkan tentang definisi risywah secara terminologis yaitu: Suatu pemberian baik berupa harta maupun benda lainnya kepada pemilik jabatan atau pemegang kebijakan/kekuasaan guna menghalalkan (atau melancarkan) yang batil dan membatilkan yang hak atau mendapatkan manfaat dari jalan yang tidak ilegal.

\section{Hubungan Makna Risywah Secara Etimologis dan Terminologis}

Kalau diperhatikan ada hubungan erat antara makna risywah secara bahasa dan istilah. Pada dasarnya asal penggunaan kata adalah sesuai dengan makna bahasa kemudian berkembang dalam kehidupan keseharian. Secara bahasa asal kata risywah yang pertama adalah: "Anak burung/ayam yang menjulurkan kepalanya pada paruh induknya seraya meminta agar makanan yang berada dalam paruh induknya di keluarkan untuknya."

Hal ini merupakan gambaran nyata bagi orang yang menerima suap. Ia ibarat seekor anak burung yang kecil dan lemah yang seolah tak mampu mencari sesuap makanan sendiri kecuali harus di suapin oleh induknya. Seandainya orang yang melakukan suap tahu bahwa apa yang dikeluarkan dari paruh tersebut ibarat muntahan tentunya dia merasa jijik. Adakah yang lebih lemah jiwanya dari seseorang yang menerima suap dari "muntahan" kantong saudaranya yang sebenarnya tidak halal baginya?

14. Abdullah Ibn Abdul Muhsin, Suap dalam Pandangan Islam ( judul asli: Jarimah al-

Risywah fiy Syari'ah al-Islâmiya), penerjemah: Muchotob Hamzah dan Subakir Saerozi, Jakarta, Gema Insani Press, 2001.

15. Abdul Aziz Dahlan, Ensiklopedi Hukum Islam, Ichtiar Baru Van Hoeve, Jakarta, Jilid $\mathrm{V}, 1996, \mathrm{hlm} .1506$

16. Depag RI, Himpunan Fatwa MUI, Proyek Sarana dan Prasarana Produk Halal, Jakarta, 2003, hlm. 274 
Adapun makna risywah yang berasal dari kata: "Yaitu tali timba yang digunakan untuk mengambil air dari dalam sumur yang dalam".

Hal tersebut ibarat seorang yang menyuap untuk mencapai tujuannya. Ia rela menjulurkan berbagai cara untuk mencapai tujuannya seperti seorang yang menjulurkan tali timba untuk memperoleh air dalam sumur.

\section{Landasan Hukum Risywah}

\section{Dalil dari Alquran}

"Dan janganlah sebahagian kamu memakan harta sebahagian yang lain di antara kamu dengan jalan yang batil dan (janganlah) kamu membawa (urusan) harta itu kepada hakim, supaya kamu dapat memakan sebahagian dari pada harta benda orang lain itu dengan (jalan berbuat) dosa, Padahal kamu mengetahui." ( QS. Al Baqarah : 188 )

"Dan kamu akan melihat kebanyakan dari mereka (orang-orang Yahudi) bersegera membuat dosa, permusuhan dan memakan yang haram. Sesungguhnya Amat buruk apa yang mereka telah kerjakan itu. Mengapa orang-orang alim mereka, pendeta-pendeta mereka tidak melarang mereka mengucapkan Perkataan bohong dan memakan yang haram? Sesungguhnya amat buruk apa yang telah mereka kerjakan itu ( QS. Al Maidah: 62 - 63 )

\section{Dalil dari Al-Hadist}

"Dari Abu Hurairoh radhiyallahu anhu berkata; Rosululloh SAW melaknat orang yang menyuap dan yang menerimanya dalam masalah hukum. ( HR.Al - Tirmdzi $)^{17}$

“Dari Abu Zur'ah dari Tsauban berkata: Rosululloh SAW melaknat orang yang menyuap dan yang menerima suap serta perantara keduanya".

\section{Pandangan Ijma' Ulama Tentang Risywah.}

Banyak sekali dalil ijma' yang menyebutkan bahwa risywah haram secara ijma'. Imam al Qurtubi ketika menafsirkan surat al Maidah ayat 42 berkata;

${ }^{17}$ Muhammad Isa at Tirmidzi, Sunan at Tirmidzi, Dar al Kutub al Ilmiyah, Beirut, 2003,hlm.344, hadits hasan no. 1336 
"Dan tidak ada perbedaan hukum dikalangan para salaf bahwa melakukan risywah untuk menolak yang hak atau dalam perkara yang dilarang merupakan riyswah(suht) yang haram".

Di dalam kitab Nihayatul Muhtaj Imam ar Romli yang dijuluki sebagai 'asy Syafi'i ash shoghir / imam syafi'i kecil menjelaskan akan hal ini: "Kapan saja seseorang mencurahkan harta untuk berhukum dengan yang tidak haq atau menolak berhukum dengan yang haq maka ia telah berbuat risywah yang di haramkan secara ijma. ${ }^{18}$

Hamd bin Abdurrohman al Junaidil dalam bukunya juga menjelaskan akan haramnya risywah secara ijma'19

“Dan sungguh telah bersepakat para shohabah dan tabiin begitu juga dengan para ulama umat atas haramnya risywah dengan segala bentuknya. Dan telah terdapat nash-nash yang menjelaskan tentang implementasi dan interpretasi apa yang terdapat dalam qur'an dan sunnah serta berusaha menjauhinya semaksimal mungkin."

Selain berbagai nukilan diatas Ibnu Qudamah dalam kitabnya alMughniy" ia berkata: "Adapun suap-menyuap dalam masalah hukum dan pekerjaan (apa saja) maka hukumnya haram tanpa ada selisih pendapat di kalangan ulama."

Imam Asy-Syaukani dalam Nailul Authar ${ }^{21}$ menukil perkataan Ibnu Ruslan tentang kesepakatan haramnya risywah.

"Ibnu Ruslan berkata dalam Syarhus Sunan, “Termasuk kemutlaqan suapmenyuap bagi seorang hakim dan para pekerja yang mengambil shadaqah, itu menerangkan keharamannya sesuai Ijma."

Imam ash-Shan'ani dalam Subulussalam (2/24) juga berkata,

“Dan suap-menyuap itu haram sesuai Ijma', baik bagi seorang qadhi/hakim, bagi para pekerja yang menangani shadaqah atau selainnya. Sebagaimana firman Allah Ta'ala, “Dan janganlah sebahagian kamu memakan harta

18. Syamsudin Muhammad bin Abi 'Abbasar Romli, Nihayatul Muhtaj, Dar al Fikr, Berut, 1984, Juz 8 hlm. 255.

19. Hamd bin Abdurrohman al Junaidil, Atsaru risywah fi ta'tsuri namwi al Iqtishodi wa Asalib Daf 'iha fi Dzilli Syariah Islamiah, al Markas al Arobi li Dirosah al Amniyyah wa Tadrib, Riyadh, 1982, hlm. 5.

${ }^{20}$ Ibnu Qudamah, Al Mughni, Darul Fikr, Beirut, 1984, Juz 11, hlm.437.

21. Muhammad ibn Ali ibn Muhammad al Syaukani, Nailul Author Min Ahadits Sayyid al Akhbar Syarh Muntaqo al Akhbar,Mesir: Maktabah Dar al-Turats, Juz 7, hlm.267 
sebahagian yang lain di antara kamu dengan jalan yang bathil dan (janganlah) kamu membawa (urusan) harta itu kepada hakim, supaya kamu dapat memakan sebahagian daripada harta benda orang lain itu dengan (jalan berbuat) dosa, padahal kamu mengetahui" . ( QS. Al-Baqarah: 188 )

\section{Menurut UU Tindak Pidana Suap}

Suap diatur dalam ${ }^{22}$ :

1. Kitab Undang-Undang Hukum Pidana (Wetboek van Strafrecht, Staatsblad 1915 No 73)

2. UU No. 11 Tahun 1980 tentang Tindak Pidana Suap (“UU 11/1980”)

3. UU No. 20 Tahun 2001 tentang Perubahan UU No. 31 Tahun 1999 tentang Pemberantasan Tindak Pidana Korupsi serta diatur pula dalam UU No. 30 Tahun 2002 tentang Komisi Pemberantasan Korupsi (“UU Pemberantasan Tipikor")

\section{Macam-macam Bentuk Risywah ${ }^{23}$}

Ibn Abidin dengan mengutip kitab al-Fath, mengemukakan empat macam bentuk risywah, yaitu:

1. Risywah yang haram atas orang yang mengambil dan yang memberikannya, yaitu risywah untuk mendapatkan keuntungan dalam peradilan dan pemerintahan.

2. Risywah terhadap hakim agar dia memutuskan perkara, sekalipun keputusannya benar, karena dia mesti melakukan hal itu (haram bagi yang memberi dan menerima).

3. Risywah untuk meluruskan suatu perkara dengan meminta penguasa menolak kemudaratan dan mengambil manfaat. Risywah ini haram bagi yang mengambilnya saja. Sebagai alasan risywah ini dapat dianggap upah bagi orang yang berurusan dengan pemerintah. Pemberian tersebut digunakan untuk urusan seseorang, lalu dibagi-

22. http://consultanonline.wordpress.com/tahukah-kamu/kejahatan-pidana/beda-suapdan-gratifikasi

23. Muhammad Amin, Hasyiyah Ibn Abidin, Darul Fikri, Beirut, 1386 H. 
bagikan. Hal ini halal dari dua sisi seperti hadiah untuk menyenangkan orang.

Akan tetapi dari satu sisi haram, karena substansinya adalah kedzaliman. Oleh karena itu haram bagi yang mengambil saja, yaitu sebagai hadiah untuk menahan kezaliman dan sebagai upah dalam menyelesaikan perkara apabila disyaratkan. Namun bila tidak disyaratkan, sedangkan seseorang yakin bahwa pemberian itu adalah hadiah yang diberikan kepada penguasa, maka menurut ulama Hanafiyah tidak apa-apa. Kalau seseorang melaksanakan tugasnya tanpa disyaratkan, dan tidak pula karena ketama'annya, maka memberikan hadiah kepadanya adalah halal, namun makruh sebagaimana yang diriwayatkan dari Ibnu Mas'ud.

4. Risywah untuk menolak ancaman atas diri atau harta, boleh bagi yang memberikan dan haram bagi orang yang mengambil. Hal ini boleh dilakukan karena menolak kemudaratan dari orang muslim adalah wajib, namun tidak boleh mengambil harta untuk melakukan yang wajib.

\section{Syarat-syarat di Bolehkannya Risywah}

Hukum asal dari risywah adalah haram, dan dibolehkan pada kondisi dan saat tertentu dengan syarat sebagai berikut.

1. Darurat; ${ }^{24}$ Yang dimaksud dengan keadaan dharurat mempunyai dua pengertian yaitu khusus dan umum.

a. Darurat dalam pengertian khusus merupakan suatu kepentingan esensial yang jika tidak dipenuhi, dapat menyebabkan kesulitan yang dahsyat yangmembuat kematian.

b. Darurat dalam pengertian umum dan lebih luas merujuk pada suatu hal yang esensial untuk melindungi dan menjaga tujuantujuan dasar syariah. Dalam bahasa Imam Syatibi sesuatu itu disebut esensial, karena tanpanya, komunitas masyarakat akan disulitkan oleh kekacauan, dan dalam ketiadaan beberapa diantara mereka, manusia akan kehilangan keseimbangannya

24 . Muhammad Tahir Mansoori, Kaidah-Kaidah Fiqih Keuangan dan Transaksi Bisnis, Ulil Albaab Institute Pasca Sarjana Universitas Ibnu Khaldun Bogor, Bogor, 2010, hlm.77-81. 
serta akan dirampas kebahagiaannya di dunia ini dan kejayaannya di akherat nanti.

Dapat diamati bahwa perhatian utama dari definisi darurat menurut imam Syatibi adalah untuk melindungi tujuan dasar syaria, yaitu menjaga agama, nyawa, keturunan, akal, kesehatan, menjaga dan melindungi kemulian serta kehormatan diri.

Adapun darurat tersebut memiliki syarat-syarat yang harus di penuhi diantaranya:

a. Darurat itu harus nyata bukan spekulatif atau imajinatif.

b. Tidak ada solusi lain yang ditemukan untuk mengatasi penderitaan kecuali hal tersebut.

c. Solusi itu (dalam hal ini risywah yang diambil) harus tidak menyalahi hak-hak sacral yang memicu pembunuhan, pemurtadan, perampasan harta atau bersenang-senang dengan sesama jenis kelamin.

d. Harus ada justifikasi kuat untuk melakukan rukhsoh / keringanan tersebut.

e. Dalam pandangan para pakar, solusi itu harus merupakan satusatunya solusi yang tersedia.

2. Untuk mengambil kewajiban dan hak yang hilang saat di dzalimi.

3. Tidak berlebihan dan menjadi kebiasaan.

4. Untuk Mendapatkan maslahah rojihah (riil) bukan dzoniyyah (perkiraan).

5. Tidak menghalalkan hal tersebut, namun mengingkarinya dan senatiasa beristighfar dan berdoa kepada Allah karena pada dasarnya cara itu haram.

\section{Istilah-Istilah Yang Berkaitan Dengan Risywah Dalam Fikih Islam}

Terdapat beberapa istilah di dalam terminologi syari'ah yang memiliki hubungan makna dengan istilah risywah. Istilah-istilah tersebut akan disebutkan sebagai berikut:

1. Mushana'ah 
Di dalam al-Mu'jam al-Wasith disebutkan, kata mushana'ah memiliki arti melakukan sesuatu untuk orang lain, agar orang tersebut melakukan hal lain untuknya sebagai balasan perlakuannya tersebut. Istilah mushana'ah kerap kali digunakan sebagai kiasan dari perilaku risywah. Para ulama klasik sering kali menyebut risywah dengan istilah mushana'ah.

2. Suht

Kata "suht" secara bahasa berarti, segala sesuatu yang buruk dari bentuk-bentuk usaha. Sedangkan menurut istilah, suht berarti setiap harta haram yang tidak boleh di usahakan dan di makan. Dikatakan suht karena harta ini dapat menghapus ketaatan dan menghilangkannya. ${ }^{25}$ Kata suht disebut di dalam al-Qur'an surat al-Maidah ayat 42.

Para ulama tafsir menafsirkan kata suht yang menjadi kebiasaan Yahudi ini sebagai risywah. Namun demikian, kata suht adalah lafaz yang masih bersifat umum, yaitu segala macam harta haram yang tidak boleh diambil dan dimakan, suht meliputi riba, suap, rampasan, hasil judi, harta curian, ongkos pelacur, mahar tukang tenung, dan segala bentuk harta yang didapatkan dari jalan yang batil. Sementara risywah bersifat lebih khusus dan merupakan bagian dari suht.

\section{Hadiah}

Hadiah berarti sesuatu yang diberikan kepada orang lain karena sikap memuliakan dan rasa cinta. ${ }^{26}$ Dikatakan ahdaytu lahu wa ilaihi "Aku memberikan hadiah kepadanya". Dan makna At-tahaadi adalah saling memberi hadiah dan jama'nya Hadaaya dan Hadaawa ini adalah bahasa penduduk madinah. ${ }^{27}$

Namun demikian, tidak semua praktik memberi dan menerima hadiah dapat dibenarkan di dalam syari'ah. Di antara hadiah yang tidak diperbolehkan di dalam Islam adalah hadiah yang diberikan untuk pengendali kebijakan, pemegang wewenang dan otoritas, orang yang

\footnotetext{
25. Tim Kementerian Wakaf dan Urusan Islam Kuwait, al-Mausu'ah al-Fighiyyah alKuwaitiyah, Dar al-Shofwa; Mesir,1427,hlm.255

26. Ibrahim Mustafa, al-Mu'jam al-Wasith, Istanbul: al-Maktabah alIslamiyah,1972,hlm.347

27. Muhammad Abdullah Ath-Thawil, kapan hadiah=suap, Surabaya: pustaka yassir,2010,hlm.16
} 
bertugas menjalankan pelayanan publik dan hakim yang hendak memutuskan suatu perkara.

Hal ini disebabkan oleh motivasi dan tujuan yang tersembunyi dari pemberian hadiah tersebut, yaitu untuk mendapatkan keuntungan, pekerjaan, perlindungan, dukungan maupun pertolongan. Kalau sudah demikian bentuknya, maka itu bukan hadiah lagi sebagaimana yang telah didefinisikan, melainkan sudah merupakan bentuk suap.

Al-Qardhawi menyebutkan bahwa penamaan suap dengan istilah hadiah tidak akan merubah statusnya dari haram menjadi halal. ${ }^{28}$

\section{Hibah}

Yaitu pemberian yang diberikan kepada seseorang dengan tanpa mengharapkan imbalan dan tujuan tertentu. Perbedaannya dengan risywah adalah bahwa Ar-Raasyi yaitu pemberi suap memberikan sesuatu karena ada tujuan dan kepentingan tertentu, sedangkan Al-Waahib atau pemberi hibah memberikan sesuatu tanpa tujuan dan kepentingan tertentu.

\section{Shadaqoh}

Yaitu pemberian yang diberikan kepada seseorang karena mengharapkan keridhoaan dan pahala dari Allah Swt. Seperti halnya zakat ataupun infaq. Perbedaannya dengan risywah adalah bahwa seseorang yang bersedekah ia memberikan sesuatu hanya karena mengharapkan pahala dan keridhoaan Allah semata tanpa unsur keduniawian yang dia harapkan dari pemberian tersebut.

\section{Istilah-Istilah Yang Berkaitan Dengan Risywah Dalam UU Tindak Pidana Suap}

\section{a. Gratifikasi}

Gratifikasi adalah, Pemberian dalam arti luas, yakni meliputi pemberian uang, barang, rabat (discount), komisi, pinjaman tanpa bunga, tiket perjalanan, fasilitas penginapan, perjalanan wisata, pengobatan cuma-cuma, dan fasilitas lainnya. Gratifikasi tersebut baik yang diterima di dalam negeri

28. Yusuf Qardhawi, halal dan haram dalam Islam, penerj Wahid Ahmadi Jasiman, Jakarta: Gema Insani press,2001,hlm.464 
maupun di luar negeri dan yang dilakukan dengan menggunakan sarana elektronik atau tanpa sarana elektronik. ${ }^{29}$

Di dalam buku Saku Memahami Gratifikasi yang diterbitkan Komisi Pemberantasan Korupsi (KPK) dijelaskan contoh-contoh pemberian yang dapat dikategorikan sebagai gratifikasi yang sering terjadi, yaitu: ${ }^{30}$

1. Pemberian hadiah atau parsel kepada pejabat pada saat hari raya keagamaan, oleh rekanan atau bawahannya.

2. Hadiah atau sumbangan pada saat perkawinan anak dari pejabat oleh rekanan kantor pejabat tersebut

3. Pemberian tiket perjalanan kepada pejabat atau keluarganya untuk keperluan pribadi secara cuma-Cuma

4. Pemberian potongan harga khusus bagi pejabat untuk pembelian barang dari rekanan

5. Pemberian biaya atau ongkos naik haji dari rekanan kepada pejabat

6. Pemberian hadiah ulang tahun atau pada acara-acara pribadi lainnya dari rekanan

7. Pemberian hadiah atau souvenir kepada pejabat pada saat kunjungan kerja

8. Pemberian hadiah atau uang sebagai ucapan terima kasih karena telah dibantu.

\section{Perbedaan Risywah dengan Hadiah}

Hari ini banyak orang melakukan risywah dengan dalih memberi hadiah. Hampir setiap tahun para pejabat kebanjiran parcel dengan dalih memberi hadiah. Padahal dalam Islam terdapat perbedaan antara hadiah dan risywah. Memang sumuanya berupa pemberian. Namun hadiah adalah pemberian yang dianjurkan dan riywah adalah pemberian yang di haramkan.

\footnotetext{
29. Undang-undang Tipikor, penjelasan pasal 12B,hlm.50

30. http://consultanonline.wordpress.com/tahukah-kamu/kejahatan-pidana/beda-suapdan-gratifikasi
} 
Dari Sahabat mulia Abu Hurairah Radhiallahu anhu berkata bahwa Rasulullah shallallahu alaihi wa sallam pernah bersabda: "Hendaklah kalian saling member hadiah niscaya kalian saling mencintai" (HR. Al Bukhari).

Kalau dilihat konteks hadits diatas maka hadiah secara umum di syriatkan dan di anjurkan. Namun kalau di korelasikan dengan hadits dibawah ini maka akan didapatkan perbedaan antara hadiah yang murni dengan hadiah yang berkedok dengan risywah.

"Abu Humaid al-Sâ'idiy berkata; bahwa Nabi SAW mengutus seorang lakilaki, yakni Ibn al-Lutbiyyah, untuk memungut zakat di kabilah Asad, ketika sampai di hadapan rasul ia berkata: "ini untuk kalian dan ini untukku sebagai hadiah". Mendengar hal itu Nabi bersabda: "mengapa ia tidak duduk saja di rumah bapak atau rumah ibunya, maka ia dapat melihat apakah ia akan diberi hadiah atau tidak, demi Allah yang jiwaku di tangan-Nya: tidak seorangpun di antara kalian yang mengambil sesuatu (tampa alasan yang benar) kecuali pada hari kiamat ia akan menggendong unta yang meringkik, sapi yang melenguh, atau kambing yang mengembek": kemudia Nabi SAW mengangkat kedua tangannya sehingga kami melihat ketiaknya, seraya berdoa:"Ya Allah bukankah aku sudah menyempaikan kepada meraka", sampai tiga kali."

Pada hadits diatas nabi saw sangat melarang pejabat amil zakat yang mengambil hadiah dari zakat yang dipungutnya. Semua itu karena kalaulah dia buka berstatus sebagai pejabat tentunya tidak mungkin orang memberi hadiah padanya. Jadi dia mendapatkan hadiah karena kedudukannya sebagai pejabat. Oleh karena itu di dalam Islam para pejabat dilarang menerima hadiah atau parcel kecuali dari orang yang ketika dia bukan menjadi pejabat sering memberi hadiah. Semua itu dalam rangka mengantisipasi terbukanya pintu-pintu riyswah. Ibnu Qudamah dalam al Mughni menjelaskan pada pembahasan. "Dan tidak menerima hadiah(bagi pejabat)kecuali dari orang yang terbiasa memberi hadiah sebelum dia menduduki jabatannya)".

"Larangan memberi hadiyah kepada pejabat tersebut karena hadiah secara umum bertujuan agar yang diberi hadiah hatinya condong sehingga diperhatikan ketika terjadi masalah hukum. Dari situlah hadiah pejabat mirip dengan risywah"

Karena urgennya masalah ini maka Imam al Bukhari dalam shahihnya membuat satu bab khusus yaitu:

“Bab Tidak Menerima Hadiah dikarekan Sebab Tertentu. 
Umar bin Abdul Aziz; "Hadiah di zaman Rosulullah SAW adalah hadiah namun pada masa ini (sekarang) hadiah tidak sama halnya dengan risywah."

Secara mendasar perbedaan antara hadiah dan risywah dapat ditinjau dari dua sisi dibawah ini:

1. Ditinjau dari segi hukum Islam.

Dari segi hukum Islam hadiah sangat dianjurkan karena pemberian hadiah merupakan sarana mempererat tali ukhuwah sesama muslim. Adapun risywah maka hukum asalnya haram. Kecuali dengan syarat yang disebutkan di atas.

2. Ditinjau dari tujuan / maksud.

Hadiah bertujuan untuk beribadah ikhlas kepada Allah semata dan mempererat ukhuwah. Adapun risywah tujuannya bukan karena Allah melainkan ada udang di balik batu dari pemberian tersebut. Dari uraian singkat di atas sangat jelas perbedaan antara hadiah dan risywah. Wallahu a'lam bishowab.

\section{Pandangan Hukum Islam Terhadap Risywah}

Sebagaimana telah di jelaskan pada bab II, Risywah adalah sesuatu yang di berikan oleh seseorang kepada hakim atau lainnya supaya orang itu mendapatkan kepastian hukum atau memperoleh keinginannya. ${ }^{31}$ Dengan definisi ini jelas bahwa suap adalah sesuatu yang diberikan oleh seseorang kepada hakim atau pejabat lainnya dengan segala bentuk dan caranya.

Sesuatu yang diberikannya itu ada kalanya berupa harta atau sesuatu yang bermanfaat bagi si penerima sehingga keinginan penyuap tersebut dapat terwujud, baik secara hak maupun batil.

\section{a. Haramnya Risywah berdasarkan Alquran, Hadits, dan Ijma'}

Islam sangat memperhatikan keselamatan harta seseorang dan mengantisipasinya supaya tidak berpindah tangan secara tidak sah, sebagaimana kasus suap-menyuap. Perpindahan harta tersebut tidak dibenarkan karena penyuap menyerahkan hartanya dengan harapan penerima suap, pejabat, atau hakim dapat menuruti kehendak penyuap.

31. Abdullah Bin Abd. Muhsin, suap dalam pandangan Islam,Jakarta : Gema Insani Press, 2001,hlm.11. 
Misalnya, diperolehnya suatu pekerjaan atau jabatan atau prioritas lain yang menggantungkan dirinya atas orang lain, dan sebagainya.

Secara tegas Islam mengharamkan umatnya menempuh jalan suap, baik kepada penyuap, penerima suap, maupun perantaranya. Hal yang dapat melatarbelakanginya adalah bahwa suap dapat menyebabkan kerusakan dan kezaliman dalam masyarakat. Sebab, dari suap muncullah permainan hukum pemutarbalikan fakta. Yang benar menjadi salah, dan yang salah menjadi bebas sehingga orang tidak dapat memperoleh hak-haknya sebagaimana mestinya. Kalau dikaji di dalam Alquran maka akan di dapati 4 ayat yang berkaitan langsung dengan risywah. Satu ayat di surat Al-Baqarah dan tiga ayat di surat Al-Maidah.

\section{Risywah adalah bentuk dari memakan harta dengan jalan yang bathil}

Allah berfirman:

“Dan janganlah sebahagian kamu memakan harta sebahagian yang lain di antara kamu dengan jalan yang batil dan (janganlah) kamu membawa (urusan) harta itu kepada hakim, supaya kamu dapat memakan sebahagian dari pada harta benda orang lain itu dengan (jalan berbuat) dosa, Padahal kamu mengetahui." ( QS.Al Baqarah : 188)

Imam Ibnu Jarir ath Thobari ${ }^{32}$ begitu juga imam Ibnu Katsir ${ }^{33}$ dalam kitab mereka menjelaskan tentang asbabun nuzul dari ayat tersebut dengan mengatakan.

"Ayat yang mulia ini turun pada seorang laki-laki yang memiliki harta dan bersengketa masalah harta tersebut dengan orang lain namun dia tidak memiliki bukti yang otentik (bahwa harta tersebut adalah miliknya). Maka pihak lawannya mengingkarinya dan pada akhirnya ia membawa persengketaan tersebut kepada para hakim dan diapun mengetahui bahwa kebenaran bersamanya dan dia juga faham bahwa (pihak lawannya) berdosa lantara memakan harta yang haram".

Adapun imam al Qurtubi menyebutkan sebab turunnya ayat ini bahwa 'Abdan Ibnu Asywa' al Hadromi dan Imru Qois terlibat dalam suatu

\footnotetext{
32 . Ibnu Jarir ath Thobari, Tafsir al-Tabari Jamiul Bayaan fi Ta'wil al Qur'an, Dar al Kutub al ilmiyyah, Beirut,1420 Juz II, hlm.190.

33. Ibnu Katsir,Tafsir Al-Qur'an Al-'Adhim, Dar Al-Kunuz Isybiliya, 1430, Mamlakah suudiyah, hlm.247.
} 
perkara soal tanah yang masing-masing tidak dapat memberikan bukti . maka Rasulullah $S A W$ menyuruh Imru Qois yang saat itu sebagai terdakwa yang ingkar agar besumpah. Maka tatkala Imru Qois hendak melaksanakan sumpah, turunlah ayat ini. ${ }^{34}$

Al-Syaukani berkata, "Ayat ini melingkupi setiap umat dan meliputi segala jenis harta. Tidak keluar dari lingkup ini kecuali harta yang telah dijelaskan kehalalannya oleh syariat. Karena jenis harta seperti itu diambil dengan cara yang benar, bukan cara yang batil, dan dimakan dengan cara yang halal, bukan dengan jalan dosa.

Sekalipun pada kenyataannya, pemilik harta tersebut tidak rela (membenci) hartanya diambil, seperti hutang, jika yang berhutang menahan diri untuk melunasinya, membayar zakat bagi yang wajib membayarnya, dan memberi nafkah bagi yang wajib memberinya.

Singkatnya, semua jenis harta yang tidak dibenarkan oleh syariat untuk diambil dari yang pemiliknya adalah merupakan harta yang dimakan dengan cara yang batil, sekalipun pemiliknya rela memberikannya dengan suka hati, seperti mahar pelacur, upah tukang tenung dan bayaran minuman keras. Batil disini memiliki makna yang lenyap atau yang hangus" ${ }^{35}$

Orang yang memakan harta orang lain dengan cara yang batil sama saja dengan ia memakan hartanya sendiri dengan batil. Oleh sebab itu Allah SWT menegaskan dengan redaksi وَلا نَأَكُلُو أَمْوَ الَكُمْ (janganlah kalian memakan harta kalian), padahal yang dimaksud adalah harta orang lain. Redaksi seperti ini banyak ditemukan di dalam al-Qur'an ketika Allah menjelaskan hubungan

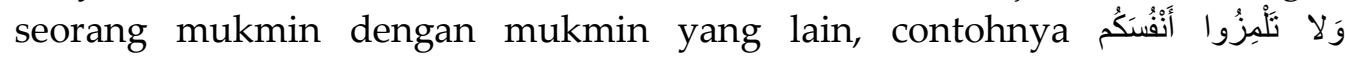
(janganlah kalian mengolok-olok diri kalian), padahal yang dimaksud adalah

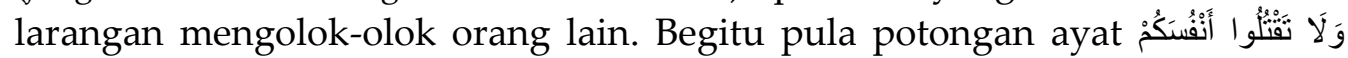
(dan janganlah kalian membunuh diri kalian), yang dimaksud di sini adalah membunuh orang lain.

Ibnu Jarir al-Thabari menerangkan hikmah dari metode seperti ini, ia berkata, "karena Allah menjadikan mukmin yang satu dengan mukmin yang lainnya bersaudara, maka yang membunuh saudaranya seperti membunuh

34. Al Qurtubi, al Jami' li Ahkamil Qur'an, Dar al hadits, Mesir, 1423, Juz I, hlm.711.

35. Muhammad ibn Ali al-Syaukani, Tafsir Fathul Qadir, Kairo: Dar al-Hadits, 2003, vol.1, hlm.262. 
dirinya sendiri, begitu pula yang mengolok-olok saudaranya, sama dengan mengolok-olok dirinya sendiri". ${ }^{36}$

Salah satu gambaran yang populer dari praktek memakan harta yang batil ini adalah dengan memberlakukan risywah (suap/sogokan). Said Hawa

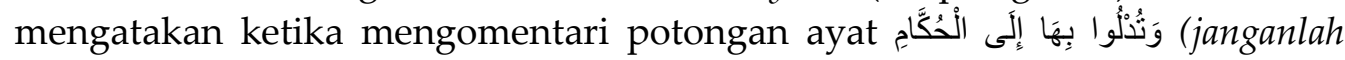
kamu membawa (urusan) harta itu kepada hakim), "Potongan ayat ini memiliki dua penafsiran. ${ }^{37}$

Pertama, janganlah kalian menbawa-bawa urusan itu dan memperkarakannya kepada hakim, sementara kalian mengetahui diri kalian dalam kebatilan, memakan harta dengan jalan dosa (kezaliman).

Kedua, kalian membawa perkara itu kepada hakim dengan menyodorkan risywah (suap/sorokan)."

Menurut al-Thabrusi, ayat ini memiliki tiga tafsiran. Pertama, tentang titipan yang tidak disertai adanya bukti (penitipan). Kedua, harta anak yatim di tangan pengelolanya, yang mana mereka datang kepada hakim dengan menyodorkan risywah untuk mendapatkan sebagian dari harta itu. Ketiga, sesuatu (harta) yang dimenangkan dengan kesaksian palsu. ${ }^{38}$

Bertolak dari beberapa tafsiran di atas, dapat disimpulkan bahwa keputusan hakim yang bertentangan dengan kebenaran tidak dapat menghalalkan harta yang diharamkan oleh syariat. Bahkan as-Syaukani menegaskan bahwa siapa pun yang menyogok seorang hakim, lalu hakim tersebut memutuskan perkara dengan memenangkannya, maka orang tersebut memakan harta dengan cara yang batil. Dan para ulama sepakat bahwa keputusan hakim tidak akan dapat merubah status sesuatu yang haram menjadi halal. ${ }^{39}$

\section{Risywah adalah kebiasaan buruk orang yahudi}

Allah berfirman :

36. Abu Ja'far Muhammad Ibn Jarir al-Thabari, Tafsir al-Thabari,hlm.189.

37. Saiid Hawa, al-Asaasu fi Tafsir,mesir: Dar as-Salam, 1405,Juz 1,hlm.434

38. Abu Ali al-Fadhl ibn al-hasan al-Thabrusi, Majma' al-Bayan fi Tafsir al-Qur'an, Beirut: Dar al-Kutub al-Ilmiyah, 1997, vol.2, hlm.19.

39. Muhammad ibn Ali al-Syaukani, Tafsir Fathul Qadir,hlm.263 
"Mereka itu adalah orang-orang yang suka mendengar berita bohong, banyak memakan yang haram. jika mereka (orang Yahudi) datang kepadamu (untuk meminta putusan), Maka putuskanlah (perkara itu) diantara mereka, atau berpalinglah dari mereka; jika kamu berpaling dari mereka Maka mereka tidak akan memberi mudharat kepadamu sedikitpun. dan jika kamu memutuskan perkara mereka, Maka putuskanlah (perkara itu) diantara mereka dengan adil, Sesungguhnya Allah menyukai orang-orang yang adil." (QS. Al- Maidah : 42)

Imam Ath Thobari ${ }^{40}$ menyebutkan riwayat dari Qotadah berkaitan dengan ayat ini. "Bahwasanya ayat ini (turun) berkaitan dengan para hakim kaum Yahudi yang senantiasa mendengarkan kedustaan serta menerima uang suap". Wahbah Zuhaili mengatakan, "Ayat ini turun berkenaan dengan orang-orang Yahudi. Seorang hakim dari kalangan Yahudi, jika didatangi oleh orang yang mengadukan perkaranya dengan membawa risywah (suap/sogok), maka mereka memenangkan orang tersebut dan berpaling dari lawannya. Maka hakim itu seyogyanya sedang memakan as-suht (uang haram), dan mendengar perkataan dusta. ${ }^{41}$

Ayat ini menerangkan tentang dua karakter buruk orang Yahudi. AsSa'di mengomentari ayat tersebut dengan mengatakan, kata سَمْع disini berarti sam'un istijabah. Maksudnya, orang-orang Yahudi tersebut karena kedangkalan akal dan keringkihan agama mereka, mereka sangat cepat menyambut ajakan kepada perkataan yang mengandung dusta.

Adapun ungkapan أكَالُونَ للسَّحْتْ , yaitu harta yang haram. Harta tersebut mereka ambil dari orang-orang awam berupa upah dengan cara yang tidak benar. Maka dalam diri mereka terkumpul dua karakter buruk, mengekor kepada kebohongan dan memakan harta haram. ${ }^{42}$

Diriwayatkan pula dari Umar ibn al-Khattab. Ali ibn Abi Thalib, Abdullah ibn Mas'ud dan Zaid ibn Tsabit bahwa yang dimaksud dengan kata adalah risywah (uang suap). Risywah juga diharamkan dalam ajaran Yahudi, karena kalau tidak demikian niscaya Allah tidak akan mencela mereka untuk memakannya sebagaimana disebutkan di dalam al-Qur'an. ${ }^{43}$

\footnotetext{
40. Ibnu Jarir ath Thobari, Jamiul Bayan... Juz 4, hlm.309

41. Wahbah Zuhaili, Tafsir al-Munir...,hlm.544.

42. Abdurrahman Nasir as-Sa'di, Tafsir Karim ar-Rahman, al-Maktabah asy-Syamilah,
} hlm.232.

43.As-Shadiq Abdurrahman al-Gharyani, Fatwa-fatwa Muamalah Kontemporer,Surabaya: pustaka Progressif,2004,hlm.124. 
Praktek risywah (suap/sogok) ini seyogyanya bukanlah masalah yang hanya menimpa umat Islam atau masyarakat modern zaman ini. Problem risywah ini adalah masalah pelik yang di praktekkan oleh kaum Yahudi sejak dahulu. Maka oleh sebab akumulasi kezhaliman mereka, Allah menghukum mereka dengan mengharamkan sesuatu yang baik yang awalnya halal. Allah berfirman,

"Maka disebabkan kezaliman orang-orang Yahudi, Kami haramkan atas (memakan makanan) yang baik-baik (yang dahulunya) Dihalalkan bagi mereka, dan karena mereka banyak menghalangi (manusia) dari jalan Allah. Dan disebabkan mereka memakan riba, Padahal Sesungguhnya mereka telah dilarang daripadanya, dan karena mereka memakan harta benda orang dengan jalan yang batil. Kami telah menyediakan untuk orang-orang yang kafir di antara mereka itu siksa yang pedih." (QS. An-Nisa': 160-161)

Bahkan budaya Yahudi yang sudah mengakar ini masih juga dipraktikkan oleh mereka pada masa Rasulullah saw. Di dalam sebuah hadits yang diriwayatkan oleh Imam Malik bahwa Rasulullah saw pernah mengutus Abdullah bin Rawahah untuk menentukan besarnya jizyah yang harus dibayar oleh orang-orang Yahudi. Mereka pun menawarkan sejumlah uang kepadanya. Menanggapi tawaran itu, ia berkata, "suap yang kalian tawarkan kepada kami adalah haram. Kami tidak mau memakannya". ${ }^{4}$

Imam al Qurtubi menyebutkan ada 2 alasan kenapa harta haram seperti risywah disebut dengan "Suht"

1. dinamakan harta haram "Suht" karena menghilangkan dan menghancur ketaatan.

2. سمي الحر ام سحتا لأنه بسحت مروءة الإنسان ). dinamakan harta haram "Suht" karena menghilangkan kehormatan. Adapun pendapat yang dipilih Imam Qurthubi adalah alasan yang pertama karena dengan hilangnya agama maka hilang pula kehormatan seseorang. Kemudian beliau menukil hadits dan atsar tentang risywah. ${ }^{45}$

"Setiap daging yang tumbuh dari harta "suht" maka api neraka lebih layak baginya. Para sahabat bertanya; Wahai Rosululloh SAW apakah yang dimaksud dengan Suht? Rosululloh saw menjawab; suht yaitu suap menyuap dalam hukum. ${ }^{46}$ Dan dari Ibnu mas'ud raodhiyallahu anhu dia berkata bahwa

\footnotetext{
44.Yusuf al-Qardhawi, Halal dan Haram Dalam Islam,Solo:Era Intermedia,2003,hlm.463.

45. Al Qurtubi, al Jami' li Ahkami al Qur'an,Juz 6,hlm.183.

46. Ash-Shadiq Abdurrahman Al-Gharyani,fatwa-fatwaMu'aamalah...,hlm.124
} 
yang di maksud dengan 'suht' yaitu seseorang memutuskan suatu perkara bagi saudaranya kemudian memberinya hadiah dan diterima hadiah tersebut".

Firman Allah SWT surat al Maidah 62-63.

“Dan kamu akan melihat kebanyakan dari mereka (orang-orang Yahudi) bersegera membuat dosa, permusuhan dan memakan yang haram. Sesungguhnya Amat buruk apa yang mereka telah kerjakan itu. Mengapa orang-orang alim mereka, pendeta-pendeta mereka tidak melarang mereka mengucapkan Perkataan bohong dan memakan yang haram? Sesungguhnya amat buruk apa yang telah mereka kerjakan itu (QS.Al Maidah: 62-63)

Secara eksplisit (mantuq) para mufasir tidak menyebutkan sebab turunnya ayat ini. Namun demikian secara implisit (mafhum) mereka menyebutkan bahwa ayat tersebut turun kepada kaum Yahudi yang terbiasa berbuat risywah dalam kehidupan mereka.

Imam Ibnu Katsir menukil riwayat dari Ibnu Abbas radhiyallahu anhuma dalam menafsirkan ayat ini bahwa beliau berkata; "Tidak ada di dalam al Qur'an suatu ayat yang lebih dahsyat mencela kaum Yahudi selain ayat tersebut." ${ }^{47}$

Adapun tafsir ayat ini menurut Ibnu Jarir adalah mereka (orang-orang Yahudi) yang disifatkan Allah di dalam ayat ini yaitu kebanyakan mereka saling berlomba-lomba dalam bermaksiat kepada Allah dan menyelisihi perintahnya. Begitu juga melanggar batasan-batasan Allah dalam permasalahan halal dan haram seperti dalam memakan "suht" itulah harta yang mereka ambil dari manusia atas persoalan hukum yang bertentangan dengan hukum Allah." 48

Dari uraian pendapat para mufasirin diatas maka dapat kita kerucutkan bahwa Allah mengharamkan risywah dimana hal tersebut merupakan kebiasaan orang-orang Yahudi . Di dalam surat al Baqarah ayat 188 Allah melarang memakan harta dengan cara batil atau haram apapun jalannya. Namun di ayat tersebut terdapat qorinah (bukti yang menguatkan) bahwa yang dimaksudkan adalah risywah. Larangan tersebut diperkuat dengan ayat 42, dan 63 surat al Maidah yang merupakan celaan yang amat buruk bagi orang-orang Yahudi karena melakukan risywah. Maka jelas sekali pandangan Alquran bahwa risywah merupakan kejahatan publik yang di

\footnotetext{
47. Ibnu Katsir,Tafsir Quran Al-'adhim,hlm.633

48. Ibnu Jarir at-Tabari, Tafsir al-Tabari,Juz 4,hlm.638
} 
haramkan oleh Allah dan merupakan kebiasaan orang-orang kafir dari kalangan Yahudi.

\section{b. Nash Hadits}

Banyak sekali hadits-hadits yang menjelaskan tentang keharaman risywah. Imam at Tirmidzi meriwayatkan dalam Sunannya. ${ }^{49}$

"Dari Abu Hurairoh radhiyallahu anhu berkata; Rosululloh SAW melaknat orang yang menyuap dan yang menerimanya dalam masalah hokum". ( HR. Al - Tirmdzi)

Hadits tersebut disebutkan juga oleh Imam al hakim dalam kitab beliau al Mustadrok dengan tanpa menyebutkan lafadz (فَي الحُكْمِم

Adapun Imam Ahmad dalam Musnadnya menyebutkan hadist yang senada dengan hadits diatas. Namun setelah diteliti para ulama derajat hadits tersebut dhoif (lemah). ${ }^{51}$ "Dari Abu Zur'ah dari Tsauban berkata: Rasulullah SAW melaknat orang yang menyuap dan yang menerima suap serta perantara keduanya".

Dari hadits-hadits tersebut Rasulullah $S A W$ tidak hanya melaknat orang yang melakukan risywah atau suap. Namun celaan juga dialamatkan bagi orang yang menerima dan perantara risywah. Hadits-hadits diatas memberikan pandangan bahwa risywah haram baik orang yang memberikan, menerimanya maupun perantara antara keduanya.

\section{c. Nash Sahabat dan Tabi'in ${ }^{52}$}

Pertama; Rasulullah saw mengutus Abdullah bin Rawahah untuk mengunjungi kaum yahudi dengan tujuan mengambil pajak hasil tanaman kurma. Namun, kaum Yahudi membangkang, dan malah memberikan sedikit uang kepada Abdullah bin Rawahah sebagai suap. Maka dia pun menjawab, “

49. Muhammad Isa at Tirmidzi, Sunan at Tirmidzi, Dar al Kutub al Ilmiyah, Beirut, 2003,h.344, hadits hasan no. 1336.

50. Muhammad bin Abdulloh al hakim ,Mustadrok 'Ala Sohihain (tahqiq Musthofa Abdul Qodir 'Atho), Dar al Kutub al Ilmiah, Beirut, 1990, Juz 4 hlm.115.hadits no. 7066.

51. Ahmad bin Muhammad bin Hambal, Musnad Imam Ahmad Hambal (tahqiq Syu'aib Arnauth dkk), Muasasah al Risalah, 2001, Juz 37 hlm 85. Hadits no 22399. Hadits ini dhoif karena dalam sanadnya terdapat Laits bin Abi Salim.

52. Abdullah Bin Abd. Muhsin, suap dalam pandangan Islam, hlm.52. 
Adapun apa-apa yang kamu tawarkan brupa suap, maka sesungguhnya itu adalah makanan haram, kami tidak akan memakannya". (HR. Malik)

Kedua; Umar Ibnu Khathab berkata dalam suratnya yang dikirimkan kepada Gubernur Sa'ad bin Abi Waqqash, " jangan mengambil orang musyrik sebagai juru tulis bagi orang-orang muslim, sebab mereka mengambil suap dalam agamanya, sedangkan tidak ada suap sedikitpun dalam agama Allah". Perkataan Umar bahwa suap itu tidak ada dalam agama Allah maksudnya adalah suap itu diharamkan.

Ketiga; Diriwayatkan dari Ibnu Syaibah dengan sanad yang sahih, dari wail saudara sekandung Abi Salamah, yaitu salah satu tokoh tabi'in, berkata, "jika seorang hakim mengambil hadiah berarti dia memakan harta haram, dan jika dia mengambil suap, maka itu akan membawanya kepada kekufuran."

Keempat; Imam Thabrani meriwayatkan dari Ibnu Mas'ud, dia berkata, "Suap dalam proses hukum itu termasuk kufur dan kufur terhadap manusia adalah termasuk haram".

\section{d. Ijma'}

Banyak sekali dalil ijma' yang menyebutkan bahwa risywah haram secara ijma'. Imam al Qurtubi ketika menafsirkan surat al Maidah ayat 42 berkata:

"Dan tidak ada perbedaan hukum dikalangan para salaf bahwa melakukan risywah untuk menolak yang hak atau dalam perkara yang dilarang merupakan riyswah(suht) yang haram".

Di dalam kitab Nihayatul Muhtaj Imam ar Romli yang dijuluki sebagai 'asy Syafi'i ash shoghir/imam syaf'i kecil menjelaskan akan hal ini.

"Kapan saja seseorang mencurahkan harta untuk berhukum dengan yang tidak haq atau menolak berhukum dengan yang haq maka ia telah berbuat risywah yang di haramkan secara ijma". ${ }^{53}$

Hamd bin Abdurrohman al Junaidil dalam bukunya juga menjelaskan akan haramnya riswah secara ijma'54

53. Syamsudin Muhammad bin Abi 'Abbasar Romli, Nihayatul Muhtaj, Dar al Fikr, Berut, 1984, Juz 8 hlm. 255. 


\section{Bahgia}

“ Dan sungguh telah bersepakat para shohabah dan tabiin begitu juga dengan para ulama umat atas haramnya risywah dengan segala bentuknya. Dan telah terdapat nash-nash yang menjelaskan tentang implementasi dan interpretasi apa yang terdapat dalam qur'an dan sunnah serta berusaha menjauhinya semaksimal mungkin".

Selain berbagai nukilan diatas Ibnu Qudamah dalam kitabnya alMughniy5s ia berkata: "Adapun suap-menyuap dalam masalah hukum dan pekerjaan (apa saja) maka hukumnya haram tanpa ada selisih pendapat di kalangan ulama".

Imam Asy-Syaukani dalam Nailul Authar ${ }^{56}$ menukil perkataan Ibnu Ruslan tentang kesepakatan haramnya risywah.

“Ibnu Ruslan berkata dalam Syarhus Sunan, “Termasuk kemutlaqan suapmenyuap bagi seorang hakim dan para pekerja yang mengambil shadaqah, itu menerangkan keharamannya sesuai Ijma".

Imam ash-Shan'ani dalam Subulussalam (2/24) juga berkata,

“Dan suap-menyuap itu haram sesuai Ijma', baik bagi seorang qadhi/hakim, bagi para pekerja yang menangani shadaqah atau selainnya. Sebagaimana firman Allah Ta'ala, "Dan janganlah sebahagian kamu memakan harta sebahagian yang lain di antara kamu dengan jalan yang bathil dan (janganlah) kamu membawa (urusan) harta itu kepada hakim, supaya kamu dapat memakan sebahagian daripada harta benda orang lain itu dengan (jalan berbuat) dosa, padahal kamu mengetahui. ( QS. Al-Baqarah: 188 )

\section{Metode Penetapan Hukum Risywah}

Sebelum di tetapkan delik suap sebagai delik dalam harta benda, ada baiknya diketahui dahulu kriteria suap dan kriteria masalah-maslah yang menyangkut harta benda lainnya, yaitu sebagai berikut. ${ }^{57}$

1. Adanya saksi

54. Hamd bin Abdurrohman al Junaidil, Atsaru risywah fi ta'tsuri namwi al Iqtishodi wa Asalib Daf 'iha fi Dzilli Syariah Islamiah, al Markas al Arobi li Dirosah al Amniyyah wa Tadrib, Riyadh, 1982, hlm. 5.

55. Ibnu Qudamah, Al Mughni, Darul Fikr, Beirut, 1984, Juz 11, hlm.437.

56. Muhammad ibn Ali ibn Muhammad al Syaukani, Nailul Author Min Ahadits Sayyid al Akhbar Syarh Muntaqo al Akhbar,Mesir: Maktabah Dar al-Turats, Juz 7, hlm.267

57 Adullah Bin Abd. Muhsin, suap dalam pandangan islam,,,hlm 54 
2. Adanya pengakuan dari yang bersangkutan

3. Adanya bukti yang nyata

1. Adanya Saksi

a. Dua Orang Saksi Laki-laki

firman Allah Swt: “.......Dan persaksikanlah dengan dua orang saksi dari orang laki-laki ( di antaramu )....." ( Al-Baqarah : 282 )

Ayat tersebut menetapkan bahwa dalam penyelesaian masalah utang harus dengan dua orang saksi laki-laki. Utang itu menyangkut harta benda dan suap itupun kejahatan dalam harta benda. Maka, jelas bahwa kriteria utang- piutang dan suap itu sama dengan kriteria masalah yang menyangkut harta benda lainnya.

b. Satu Orang Saksi Laki-laki dan Dua Orang Saksi Perempuan

Firman Allah Swt: "Jika tidak ada dua orang laki-laki, maka boleh seorang laki-laki dan dua orang perempuan dari saksi-saksi yang kami ridhai,.." ( AlBaqarah : 282).

Allah menganggap bahwa satu orang laki-laki dan dua orang perempuan sebagai saksi dalam penyelesaian masalah-masalah harta benda sudah memenuhi syarat dalam penyelesaian hukum suap. Maka, kriteria suap dapat ditetapkan dengan kriteria-kriteria masalah yang menyangkut harta benda.

Dalam hal ini, bukan berarti saksi yang terdiri dari satu orang laki-laki dan dua orang perempuan berfungsi sebagai pengganti lantaran tidak ada dua orang laki-laki sebagai saksi. Semua itu diserahkan kepada yang bersangkutan untuk memperoleh hak-haknya dalam masalah harta. Yang mana saja dimungkinkan baginya, asalkan telah memenuhi syarat. Hanya saja persaksian seorang laki-laki tidak sebanding perempuan karena pada umumnya perempuan banyak kelemahan baik fisik maupun mental jika sudah berada di depan persidangan.

c. Satu Orang Saksi Disertai Sumpah

Hadits: "Diriwayatkan dari ibnu Abbas bahwa Rasulullah saw. Pernah memutuskan suatu perkara didasarkan pada sumpah dari seorang saksi." (HR. Ahmad, At-Tirmidzi, dan Ibnu Maajah). 
Secara teknis, dalam pelaksanaan persaksian, harus didahulukan saksi dari pada sumpah, bukan sebaliknya. Karena sumpah itu di maksudkan sebagai penguat posisi saksi.

2. Adanya pengakuan dari yang bersangkutan

Suatu perkara dapat dipastikan terjadi manakala ada pengakuan sendiri dari korban. Pengakuan tersebut bisa diterima apabila yang bersangkutan sudah mukallaf (dewasa).

3.Adanya Bukti yang Nyata

Suatu perkara bisa dibuktikan dengan bukti-bukti yang autentik, sebagaimana dituturkan dalam Alquran yang mengisahkan tentang saudarasaudara Nabi Yusuf as: "Mereka menjawab, balasannya ialah pada siapa diketemukan (barang yang hilang) dalam karungnya, maka dia sendirilah balasannya ( tebusannya )...." (Yusuf : 75).

Dalam kisah di atas, kita mengetahui bahwa mereka menjadikan sesuatu yang ditemukan di dalam karung dijadikan barang bukti pencurian. Jika ditemukan bukti itu berarti dia betul-betul mencuri, kalau tidak, berarti yang bersangkutan bebas dari tuduhan. Jadi, dalam memutuskan suatu perkara tidak boleh sembarangan tanpa bukti-bukti yang kuat.

Dalam hal ini, barang bukti dapat dipegang oleh saksi untuk diperlihatkan kepada orang yang terkait, terutama kepada orang yang menerima suap kalau dia berusaha mengelak. Misalnya, barang bukti itu bisa berupa uang, nomor rekening, atau bukti-bukti lain yang dapat diperlihatkan secara nyata dan langsung, sehingga tuduhan yang dijatuhkan dapat diyakini kebenarannya.

\section{Hukuman Ta'zir Bagi Penyuap, Penerima, dan Perantaranya}

Tidak ada ketentuan dalam nash Al-Qur'an tentang sanksi bagi orang yang telah berulang kali tersangkut tindak kejahatan suap. Semua diserahkan pada kebijaksanaan masing-masing hakim dengan tetap berpegang pada syariat Islam. Sanksi tersebut disesuaikan situasi dan kondisi tertuduh serta melihat kemaslahatan yang perlu dijaga sehingga dalam menjatuhkan hukuman nantinya perlu diperberat atau sebaliknya.

Sebab, kasus suap ini bukan termasuk dalam hukum qishash atau hadd, melainkan ta'zir. Ta'zir adalah pelanggaran atas hukum syara' (wajib dan 
haram), tetapi belum ditetapkan kadar sanksinya ${ }^{58}$ secara syar'i maka diserahkan kepada wali amri (qadhi/khalifah/hakim) untuk menetapkan sanksinya. karena harta yang diperoleh merupakan harta yang syubhat.

Orang yang sudah berulang kali melakukan tindak kejahatan suapmenyuap berarti sudah berani terang-terangan menentang hukum Islam. Oleh karena itu, dia harus dijatuhi hukuman yang berat yang sekiranya dapat membuatnya jera untuk selama-lamanya. Selain itu, harus dipublikasikan ke kalangan masyarakat karena delik suap adalah kemungkaran yang harus dijauhi dari masyarakat. Rasulullah saw bersabda, "Barangsiapa yang melihat kemungkaran, maka hendaknya dia mencegahnya dengan tangannya."

Yang dimaksud dengan tangannya dalam hadits ini adalah kekuasaan. Jadi yang pertama berkewajiban mencegah kemungkaran sebenarnya adalah para penguasa atau penegak hukum karena merekalah yang berwenang menjatuhkan hukuman. Untuk memudahkan Wali al Amri dalam memutuskan yang tidak terdapat dalam nash Al Qur'an maupun hadits, maka Wali al Amri menetapkan suatu sistem Al-Maslahah. Dan pada dasarnya tujuan awal dari hukun Islam adalah mewujudkan kebaikan, kemaslahatan sekaligus mencegah terjadinya kerusakan (mafsadah) untuk menarik manfaat dan menolak mudharat bagi seluruh umat.

Kemaslahatan umat manusia itu sifatnya aktual tidak ada habisnya karena jika tidak syari'at hukumannya yang berdasarkan maslahah-mursalah ${ }^{59}$ yang berhubungan dengan masalah baru dan tuntutan perkembangan zaman, maka pembentukan hukum hanya terkunci berdasarkan maslahah yang mendapatkan pengakuan syara'. Maksudnya apabila hukum itu hanya terpaku yang ada dalam Al Qur'an dan hadits saja, tidak memperhatikan permasalahan- permasalahan yang mungkin timbul di masa sekarang maupun dimasa yang akan datang maka hukum Islam tidak universal.

Hal semacam ini yang ditegaskan oleh Abdul Wahab Khalaf dalam Ilmu al-Ushul al-Fighnya, yang artinya: " Jumhur ulama berpendapat bahwa maslahah mursalah itu merupakan hujjah syar'i yang dipakai sebagai pembentukan hukum mengenai kejadian, peristiwa atau masalah yang hukumnya tidak ada dalam nas dan ijma'.

\footnotetext{
58. Ichtiar Baru Van Hoeve, Ensiklopedi Hukum Islam,Juz 5,hlm.1774

59. Maslahah mursalah adalah, menurut Imam al-Ghazali, sebuah ungkapan mengenai suatu hal yang mendatangkan manfaat dan menolak kerusakan atau kemudharatan.
} 
1. Hukuman denda

Para ulama berbeda persepsi dalam memberikan interpretasi terhadap penerapan hukuman denda ini. Dalam hal ini ada dua kelompok pendapat.

a. Kelompok ulama yang tidak setuju diterapkannya hukuman denda. Mereka yang tidak sependapat adalah Imam Abu Hanfah, Imam Syafi'i dalam Qaul Jadidnya, ulama-ulama Hambali, dan sebagian ulama-ulama Maliki. Pendapat mereka berdasarkan firman Allah Swt: "Hai orang-orang yang beriman, janganlah kamu saling memakan harta sesamamu dengan jalan yang batil,...." (An-Nisa' : 29).

Hukuman denda itu identik dengan memakan harta orang lain dengan jalan batil karena tidak ada serah terima yang sama-sama ridha di antara keduanya, sedangkan memakan harta secara batil itu dilarang, Maka hukuman itu dilarang. Diriwayatkan dari Abu Bakar ra. Bahwa Rasulullah saw bersabda, pada khutbah hari Raya Nahar ketika haji Wada', "Sesungguhnya, darah dan harta kamu sekalian haram." (HR. Asyaikhani dan Ahmad).

Rasulullah saw mengharamkan pelanggaran dalam masalah harta benda dan hukuman denda itu termasuk pelanggaran karena pengambilannya secara tidak sah oleh sebab itu, hukuman denda diharamkan.

b. Kelompok ulama yang setuju diterapkan hukuman denda. Mereka yang sependapat dibolehkannya hukuman denda ini adalah manyoritas yang yang bermazhab Maliki, ulama-ulama Hambali, dan Imam Syafi'i dalam Qaul Qadimnya, serta Khulafaur Rasyidin dan pembesar-pembesar sahabat. Termasuk yang condong terhadap pendapat ini adalah Abu Yusuf dari mazhab Hanafi.

Sebagian ulama Hanafiah, yaitu Abu Yusuf, mentakwilkan bahwa mengambil atau menyita harta benda sebagai hukuman denda terhadap tuduhan itu hanya sebagai barang tanggungan atau jaminan sampai dia jera tidak mengulangi perbuatannya. Setelah dia jera dan taubat, hakim harus mengembalikan harta tersebut, tetapi kalau tidak jera, harta itu dapat digunakan untuk kemaslahatan umum. Jadi, mengambil harta orang lain itu dilarang kecuali ada alasan syara'

Mereka yang sependapat dengan adanya hukuman denda mengacu pada dalil-dalil sebagai berikut. Diriwayatkan dari Abu Thalhah, dia berkata, 
“Wahai Nabi Allah, saya telah membeli minuman keras untuk anak-anak yatim yang di sekitarku. " Maka Nabi bersabda, "Tumpahkan minuman keras itu dan hancurkan gucinya."

Rasulullah saw memberi sanksi bagi orang yang memiliki arak dengan menghancurkan botol-botolnya. Cara ini termasuk dalam hukuman denda mubah. Maka, berarti hukuman denda itu diperbolehkan. "Diriwayatkan dari 'Amr bin 'Ash, Sesungguhnya Nabi saw bersama Abu Bakar dan Umar membakar harta benda orang yang curang (Korupsi) lalu mereka memukulnya."

Rasulullah saw memerintahkan kepada Sa'ad bin Abi Waqqash untuk merampas hasil buruan orang yang berburu di daerah-daerah kota Mekkah yang terlarang. "Barangsiapa yang kamu jumpai sedang berburu di daerah terlarang (di kota Mekkah) maka rampaslah hasil buruannya." (HR. Muslim)

Dalil yang menunjukkan diperbolehkannya hukuman denda adalah bahwa Ali bin Abi Thalib membakar makanan-makanan orang yang suka menimbun barang dan rumah-rumah orang yang menjual minuman keras serta merobohkan rumah Jabir bin Abdullah.

Atsar sahabat di atas dapat dijadikan sebagai dasar dalam usaha memberantas dan mencegah perbuatan mungkar yang berbentuk hukuman denda. Usaha preventif semacam ini termasuk ta'zir dengan harta atau denda sehingga dapat diambil kesimpulan bahwa hukuman denda itu diperbolehkan.

\section{Tarjih}

Para ulama yang memperbolehkan pemberlakuan hukuman denda ini memberikan argumentasi dan telah membuktikan bahwa hukuman denda berhasil membuat para pelaku kemaksiatan jera dan tidak berani mengulangi lagi perbuatan mereka. Mereka berhati-hati dan mempertimbangkan tindakan yang semula tidak pernah mereka perhitungkan. Hanya saja, dalam praktiknya hukuman denda ini harus mempertimbangkan kemaslahatan umat secara keseluruhan.

Adapun sanksi bagi pelaku tindak kejahatan suap-menyuap dengan hukuman denda itu karena dititikberatkan pada jenis perbuatannya. Jadi, 
tidak ada masalah apabila pelaku suap diberi sanksi dengan hukuman denda. Semua itu tujuannya sama, yaitu memberi pelajaran dan membuatnya jera.

\section{Hukuman Penjara}

Penjara berarti pengekangan dan penahanan. Dalam bahasa arab disebut al-habsu atau as-sijnu. Ini sesuai dengan firman Allah swt yang mengisahkan Nabi Yusuf As, "Yusuf berkata : wahai Tuhanku, penjara lebih aku sukai dari pada memenuhi ajakan mereka kepadaku...." (Yusuf: 33)

Penjara dalam syara' dimaksudkan sebagai pengekangan terhadap terpidana dan larangan untuk bergaul dengan alam bebas. Dalam masalah hukuman penjara ini, ulama fiqih ada yang pro dan ada yang kontra. Menurut ulama Hambali, hukuman penjara tidak ada dalam ketentuan syara'. Itu terbukti bahwa di masa Nabi saw, dan Abu bakar ra tidak ada penjara. Bukannya tidak pernah memenjarakan orang yang bersalah tetapi hanya menahan sebentar untuk mendidiknya atau menyuruhnya membayar denda yang setimpal dengan perbuatannya. Namun kalau dianalisis, tidak adanya penjara pada masa Rasulullah saw dan Abu Bakar ra itu bukan berarti tidak diajarkan oleh syara' karena waktu itu memang belum dibutuhkan dan belum mendesak.

Pada masa Khalifah Umar ra, pemerintah Islam sudah meluas, praktis banyak masalah yang harus dihadapi. Penjara jelas dibutuhkan sebagai salah satu sarana untuk mengantisipasinya meluasnya kriminalitas, maka didirikan penjara. Menurut jumhur ulama hukuman penjara itu diajarkan oleh syara' dengan dasar sebagai berikut.

\section{a. Dalil Al - Quran}

"Dan terhadap para wanita yang mengerjakan perbuatan keji, hendaklah ada empat orang saksi di antara kamu ( yang menyaksikan ). Kemudian apabila mereka telah memberi persaksian, maka kurunglah mereka itu dalam rumah sampai mereka menemui ajalnya, atau sampai Allah memberi jalan yang lain kepadanya." (An-Nisa': 15)

“.... atau dibuang dari negeri ( tempat kediamannya )...." (Al-Maidah : 33)

Imam malik dan ahli kuffah menafsirkan hukuman pembuangan tersebut sama dengan penjara karena dibuang berarti dikucilkan dari pergaulan masyarakat luas, sebagaimana di kurung dalam penjara. 


\section{b. Sunnah Rasul}

"Bahwasannya Rasulullah saw pernah memenjarakan seorang laki-laki karena suatu tuduhan kemudian beliau membebaskannya." (HR. AlKhamsah kecuali Ibnu Majah )

c. Ijma' Sahabat

Umar ibnu Khathab ra, dan Usman bin Affan ra menyepakati diberlakukannya hukuman penjara, dan sahabat-sahabat yang lain pun tidak ada yang memperselisihkan. Umar ibnu Khathab ra, pernah membeli sebuah rumah kepada shafwan bin Umayyah dengan harga empat ribu dirham untuk dijadikan penjara. Waktu itu ia memenjarakan al-Habiah karena kemaksiatannya dan Dhabyan at-Tamimi karena mempersoalkan surah adzDzaariyat, al-Mursalat, an-Naziat, yang intinya mengajak orang mendalami masalah musykilah dan ghaib. Maka oleh Umar ra ia pukul berulang kali dan di asingkan ke Irak dengan menulis surat kepada gubernur Irak, supaya Dhabyan dikucilkan dari pergaulan. Utsman bin Affan ra juga pernah menghukum penjara seorang pencuri dan pembunuh dari Bani Tamimi yaitu Dhabi' ibnu Harits sampai akhirnya dia mati dalam penjara.

Kasus di atas menunjukkan bahwa syari'at Islam mengajarkan adanya hukuman penjara dengan tujuan supaya narapidana dapat diarahkan dan di didik menjadi baik dan tidak lagi mengulangi perbuatan mereka. Para penegak hukum tidak boleh melampaui batas yang telah diajarkan syara' dan tidak boleh bertindak yang menyimpang dari tujuan hukuman penjara sendiri. Di sini diharapkan adanya keselarasan antara penahanan dan pengarahan tujuan yang hendak dicapai sehingga penjara iti sendiri akan membuahkan hasil yang hakiki.

3. Hukuman Dera dan Pukulan

Di antara hukuman berbentuk ta'zir yang diajarkan dalam Alquran, sunnah, maupun ijma' adalah dera ( cambuk) dan pukulan. Hukuman semacam ini memiliki makna yang dalam bagi pelanggar hukum.

a. Dalil Alquran

"Perempuan yang berzina dan laki-laki yang berzina maka deralah tiap-tiap seorang..." ( an-Nuur : 2)

b. Sunnah Rasul

Diriwayatkan dari jabir, Nabi Muhammad saw. Bersabda, 
“Takutlah kamu sekalian kepada Allah dalam urusan kaum wanita. Kamu mengambil mereka dengan amanat Allah dan kamu menghalalkan farji mereka dengan izin Allah. Istri-istrimu wajib atas mereka terhadap kamu, yaitu jangan sampai ada orang lelaki yang tidak kamu sukai menginjak tempat tidurmu. Jika mereka melakukan itu, maka pukullah mereka dengan pukulan yang tidak membekas (membahayakan)." (HR. Muslim) jenis $t a^{\prime} z$ ir

Hadits di atas menunjukkan adanya pemukulan sebagai salah satu

c. Ijma' Sahabat

Imam Ahmad pernah bercerita tentang Ali bin Abi Thalib ra, pada bulan Ramadhan, Ali ra mendapat laporan tentang seseorang dari suku Najsyi yang minum minuman keras. Maka, ia mencambuk orang itu dengan delapan puluh kali cambukan sebagai hukuman hadd dan menambahnya dengan dua puluh kali cambukan sebagai penyucian dirinya di bulan Ramadhan. Tidak seorang pun yang menentang ataupun mempermasalahkan tindakan Ali ra tersebut. Sahabat yang lain bersepakat akan hal itu. Begitu pula ulama pada periode sesudahnya. Dengan demikian secara ijma' pun hukuman cambuk dan pemukulan ini sebagai salah satu hukuman $t a^{\prime} z i r$. Atas dasar itulah maka pelaku delik suap, baik penyuap, penerima suap, maupun perantaranya dapat divonis hukuman dera atau pemukulan, selama tidak menyimpang dari tujuan kemaslahatan yang hakiki.

\section{Hukuman Pemecatan Jabatan}

Yang dimaksud dengan pemecatan adalah nasib buruk yang dialami seseorang atas jabatan atau pekerjaannya sebagai akibat ulahnya sendiri. Pemecatan ini termasuk dalam jenis hukuman ta'zir. Biasanya, hukuman ini berlaku bagi pejabat atau hakim yang telah terkena suap dan sejenisnya. Atau dia telah berulang kali berbuat kesalahan yang cukup fatal, menyalahgunakan amanat yang telah di percayakan kepadanya.

Pemecatan ataupun mutasi jabatan ini dilakukan dengan maksud agar kesalahan yang telah dilakukan oknum tersebut tidak menjalar dan ditiru oleh pejabat yang lain. Menurut Ibnu Taimiyah, hukuman pemecatan ini pernah dilakukan oleh Nabi Muhammad saw dan sahabatnya. Oleh karenanya, jika diketahui ada oknum yang mabuk-mabukan, maka ia harus dipecat setelah ia didera empat puluh kali. 
Manyoritas ulama-ulama fiqih, seperti Hanafiyah dan syafiiyyah, sepakat dengan diberlakukannya hukuman pemecatan terhadap para penerima suap, bahkan sebagian dari mereka ada yang berpendapat, hanya karena ketidakadilannya ( pejabat dan hakim) ia harus dipecat dari jabatannya. Selain hukuman pemecatan, penulis melihat bahwa bagi pengkhianat, orang yang menyalahgunakan jabatan, dijatuhi hukuman yang lain. Misalnya. Dilepas hak-haknya yang biasa diberikan negara kepadanya. Semua itu diakibatkan nafsu serakahnya sendiri yang membawa kerusakan bagi diri maupun lingkungannya.

\section{Hukuman bagi orang yang Berulang Kali Melakukan Delik Suap}

Para pakar hukum telah merumuskan hukuman bagi orang yang berulang kali melakukan tindak kejahatan serta orang yang mengulangi kejahatan yang sama, meski dia sudah pernah dijatuhi hukuman. Orang yang berulang kali melakukan kejahatan harus dijatuhi hukuman yang lebih berat dari hukuman yang pernah dijatuhkan kepadanya. Sebab, itu menunjukkan bahwa hukuman yang pernah diterimanya tidak dapat membuatnya jera dan bertaubat. Padahal tujuan pemberian hukuman selain sebagai tebusan dari perbuatannya itu, juga agar terpidana menjadi jera, menyesal sehingga mau bertaubat kepada Allah SWT.

Dalam kitab-kitab fiqih sering dibahas hukuman bagi orang yang mengulangi tindak kejahatan ini, yaitu sebagai berikut.

a. Dalam kitab Hasyiyah, Ibnu Abidin berpendapat, " jika seseorang yang berbuat pelanggaran mempunyai sifat muruah maka tidak perlu dipenjara ataupun di $t a^{\prime} z i r$. Itu pun kalau memang ia baru pertama kali melakukan pelanggaran.

Sebagaimana sabda Rasulullah saw. Dari al-Hasan ra, "bebaskanlah orang yang mempunyai sifat muruah dari hukuman, kecuali dalam masalah hadd (HR Ahmad, Abu Dawud, Nasai dan Baihaqi)

Dia cukup dinasehati dan mau berjanji tidak akan mengulangi perbuatannya. Namun apabila ia berbuat lagi, maka ia harus dihajar sebab itu menunjukkan dirinya sudah tidak mempunyai sifat muruah (kehormatan diri) 
b. Menurut Ibnu Abdissalam, orang yang sudah berulang kali berbuat kejahatan harus dipenjara seumur hidup karena baginya hukuman ta'zir sudah tidak berarti lagi.

c. Ibnu Taimiyah dalam bukunya as- siyaasah asy-syariyyah berpendapat, “ jika seseorang mengulangi perbuatannya, padahal ia sudah pernah dijatuhi hukuman $t a^{\prime} z i r$, maka hukuman baginya harus ditambah atau diperberat sesuai dengan kadar kejahatannya. Jika kejahatannya itu sudah tidak mungkin lagi dihentikan, kecuali dengan hukuman mati, maka dia harus dijatuhi hukuman mati sebagaimana hukuman pengkhianat kaum muslimin. Begitu pula orang yang sudah empat kali bermabuk-mabukan, padahal sudah pernah di dera, dia harus dijatuhi hukuman mati."

d. Yang sependapat dengan Ibnu Taimiyah adalah pengarang Kasysyaf ulQana', Tujuan hukuman adalah untuk memberantas kejahatan di muka bumi ini. Maka, kalau ada orang yang berbuat kejahatan yang sama untuk kesekian kalinya dan tampak bahwa itu hanya dapat diberantas dengan hukuman mati, maka ia harus dihukum mati."

e. Adapun pendapat Abu Ya'la, " Hakim diperbolehkan memenjarakan seumur hidup orang yang berulang kali melakukan tindak pidana."

Dengan demikian, menambah atau memperberat hukuman ini juga berlaku Bagi oknum yang sering melakukan delik suap karena perbuatannya itu menunjukkan bahwa dia sudah tidak mempunyai sifat muruah ( harga diri ).

\section{Tujuan Hukuman}

Adapun yang menjadi tujuan pokok dalam penjatuhan hukuman dalam syari'at Islam adalah pencegahan, pembinaan atas kesalahan yang tidak ada ketentuan hududnya tidak pula kafarat. ${ }^{60}$ Pencegahan merupakan pengekang sipelaku tindak pidana untuk tidak mengulangi lagi perbuatan pidananya. Pencegahan dan menakut-nakuti, dalam syari'at Islam tidak hanya memberikan perhatian kepada pelaku tindak pidana tersebut, bahkan memberi pelajaran dan mendidik untuk berbuat lebih baik terhadap diri dan lingkungannya.

${ }^{60}$. Sayyid sabiq, fikih sunnah,jakarta:Dar Fath Lil 'Alami Al-Arabiy,2009,hlm.485 
Dalam sebuah riwayat dinyatakan bahwa Umar bin Khathab ra, pernah menjatuhkan hukuman ta'zir dan pembinaan ${ }^{61}$ dengan memotong rambut, mengasingkan, dan cambuk. Sebagaimana Dia juga pernah membakar warung para tukang khamar serta kampung tempat penjualan khamar.

Dia juga membakar istana sa'ad bin Abi Waqqash di Kufah lantaran keberadaan istana tersebut membuatnya tertutup dari rakyat. Dia membuat cambuk untuk memukul orang yang layak mendapatkan cambukan serta membuat bangunan penjara dan mencambuk wanita yang meratapi jenazah hingga rambutnya terlihat. Juga tujuannya penghinaan, ${ }^{62}$ Dikatakan ; 'azzara fulan fulanan. Artinya; dia menghina fulan sebagai pelajaran dan tindakan supaya dia jera atas dosa yang diperbuatnya.

Hukum Islam mempunyai lima tujuan ${ }^{63}$ yaitu, memelihara agama, memelihara jiwa, memelihara akal, memelihara keturunan dan memelihara harta benda. kemudian dinamakan maqasid al-tasyri, dan bila dilihat dari peringkat kepentinganya ada tiga tujuan yaitu:

1) Tujuan primer (Adharuri)

Tujuan primer hukum Islam yang pasti ada demi adanya kehidupan manusia, apabila tujuan itu tidak tercapai, maka akan menimbulkan mafsadah hidup manusia di dunia dan akhirat, bahkan merusak kehidupan itu sendiri. Kebutuhan primer ini hanya dapat tercapai bila dipeliharanya lima hal yang menjadi maqasid al tasyri' yaitu: a) Memelihara agama. b) Memelihara jiwa. c) Memelihara akal. d) Memelihara keturunan atau kehormatan. e) Memelihara harta. Termasuk hukum pidana (jinayah) yang meliputi amar ma'ruf nahi mungkar merujuk kembali kepada pemeliharaan keseluruhan tujuan hukum yang bersifat primer.

2) Tujuan sekunder (al haajiyyat)

Tujuan sekunder hukum Islam ialah terpeliharanya tujuan kehidupan manusia yang terdiri atas berbagai kebutuhan sekunder hidup manusia itu. Jika kebutuhan ini tidak dilaksanakan akan menimbulkan kesempitan dalam kehidupannya, walaupun kesempitan tersebut tidak menimbulkan kerusakan bagi kehidupan masyarakat secara umum. Contoh dalam hukum pidana

\footnotetext{
61. Ibid,hlm.486

62. Ibid,hlm. 485

63. Ahmad Al-Mursi Husain Jauhar, Maqasid Syariah,Jakarta:Amzah,2009,hlm.1
} 
adanya sistem sumpah, denda, atau dalam proses pembuktian dan persaksian dalam pidana.

3) Tujuan tersier (tahsi'niyyat)

Tujuan tersier hukum Islam adalah tujuan hukum yang ditujukan untuk menyempurnakan hidup manusia dengan cara melaksanakan sesuatu yang paling layak menurut kebiasaan dan menghindari hal-hal yang tercela bagi akal sehat. Contoh melakukan kebaikan dengan shadakoh. ${ }^{64}$

Adapun tujuan hukum bagi pelaku risywah adalah memelihara agama dan harta benda. Karena Islam mengharamkan perbuatan tersebut dan sejenisnya.

\section{Suap Menurut Undang-undang Tindak Pidana Suap}

Tindak pidana suap pada hakekatnya perbuatan yang bertentangan dengan norma kesusilaan dan moral Pancasila, yang membahayakan kehidupan masyarakat dan bangsa. Kenyataan menunjukkan bahwa perbuatan suap telah terjadi dalam berbagai bentuk dan sifatnya dalam masyarakat dan oleh karena itu harus diberantas.

Undang-undang yang melarang perbuatan suap yang berlaku hingga sekarang ini, hanya terbatas pada bidang tertentu dan oleh pelaku yang mempunyai kedudukan tertentu, misalnya perbuatan suap yang diatur dalam Kitab Undang-undang Hukum Pidana dihubungkan dengan Undang-undang Nomor 3 Tahun 1971. Selain Undang-undang tersebut di atas, di mana pelakunya mempunyai kedudukan tertentu, maka terdapat perbuatan suap dalam bidang lain seperti yang tercantum dalam Undang-undang Nomor 15 Tahun 1969 tentang Pemilihan Umum Anggota Badan Permusyawaratan/Perwakilan Rakyat sebagaimana telah diubah terakhir dengan Undang-undang Nomor.2 Tahun 1980 tentang Perubahan atas Undang-undang Nomor 15 Tahun 1969 tentang Pemilihan Umum Anggota Badan Permusyawaratan/Perwakilan Rakyat sebagaimana telah diubah dengan Undang-undang Nomor 4 Tahun 1975 (Lembaran Negara Tahun 1980 Nomor 24, Tambahan Lembaran Negara Nomor 3163).

1995), hlm. 101-103.

64. Juhaya S. Praja, Filsafat Hukum Islam, (Bandung: LPM Universitas Islam Bandung, 
Dalam rangka pembinaan watak bangsa yang bersih dan kuat berdasarkan Pancasila, maka perbuatan suap dalam berbagai bentuk dan sifatnya perlu dilarang. Namun demikian perlu diadakan pembatasan, yaitu terbatas pada perbuatan suap yang menyangkut kepentingan umum.

Perbuatan suap dapat juga terjadi di luar negeri, baik yang dilakukan oleh warga negara Indonesia, maupun oleh warga negara asing, dan oleh karena itu ketentuan dalam undang-undang ini harus pula menjangkau pelaku perbuatan suap tersebut dengan memberikan ketentuan pidana Indonesia.

Menurut Undang-undang Republik Indonesia Nomor. 11 Tahun 1980 tentang tindak pidana suap.

Pasal 2: Suap di definisikan sebagai memberi atau menjanjikan sesuatu kepada seseorang dengan maksud untuk membujuk supaya orang itu berbuat sesuatu atau tidak berbuat sesuatu dalam tugasnya, yang berlawanan dengan kewenangan atau kewajibannya yang menyangkut kepentingan umum. ${ }^{65}$

Pasal 3: Menerima sesuatu atau janji, sedangkan ia mengetahui atau patut dapat menduga bahwa pemberian sesuatu atau janji itu dimaksudkan supaya ia berbuat sesuatu atau tidak berbuat sesuatu dalam tugasnya, yang berlawanan dengan kewenangan atau kewajibannya yang menyangkut kepentingan umum. ${ }^{66}$

\section{Dasar Hukum Suap}

Pada umumnya orang beranggapan suatu kejahatan korupsi merupakan kejahatan yang merugikan keuangan negara. Hal itu karena beberapa pasal tindak pidana korupsi dalam Undang-Undang Pemberantasan Tindak Pidana Korupsi (UUTPK) merumuskan adanya unsur 'merugian keuangan negara'. Tetapi, untuk kejahatan suap-menyuap tidak ada kaitannya dengan kerugian uang negara, meskipun perbuatan tersebut dikualifikasikan sebagai kejahatan korupsi.

Para pelaku suap mungkin bertanya-tanya, negara yang tidak dirugikan uangnya sepersen pun mengancamkan sanksi pidana yang cukup tinggi dan mengecap mereka sebagai koruptor, perbuatannya disamakan

65. Tim penyusun, Undang-undang Republik Indonesia; Tindak Pidana Suap ,www.pih.deplu.go.id,diakses 16/06/2014.

66. ibid 
dengan para pelaku korupsi yang merugikan uang negara miliaran rupiah. Apa yang telah mereka rugikan sehingga mereka diperlakukan demikian sering dilontarkan para pelaku suap yang merasa tidak bersalah kepada negara.

Suap sebagai kejahatan korupsi memang merupakan suatu ketentuan baru yang diatur dalam Undang-undang Tindak Pidana Korupsi ( UUTPK ) yang mulai diundangkan dengan UU No 3 Tahun 1971 dan kemudian diganti dengan UU No 31 Tahun 1999 jo UU No 20 Tahun 2001. Tetapi semua ketentuan tentang suap tersebut dioper dari KUH Pidana dalam kaitan dengan tindak pidana jabatan (ambs delicten).

Pasal-pasal KUHP yang dioper ke UUTPK adalah Pasal 209 KUHP yang mengatur penyuapan aktif (actieve omkooping atau active bribery) terhadap pegawai negeri dan Pasal 419 KUHP yang mengatur penyuapan pasif (passieve omkooping atau passive bribery) yang mengancam pidana terhadap pegawai negeri yang menerima hadiah atau janji. Kemudian Pasal 210 KUHP yang mengatur penyuapan terhadap hakim dan penasihat hukum di pengadilan serta Pasal 420 KUHP yang mengatur tentang hakim dan penasihat hukum yang menerima suap.

Perluasan tindak pidana suap dalam bentuk gratifikasi yang diatur dalam Pasal 418 KUHP kemudian juga dioper menjadi tindak pidana korupsi dengan merumuskan gratifikasi sebagai pemberian hadiah yang luas dan meliputi pemberian uang, barang, rabat/diskon, komisi, pinjaman tanpa bunga, tiket perjalanan, fasilitas penginapan, perjalanan wisata, pengobatan cuma-Cuma, dan fasilitas lainnya.

Tetapi, tidak semua suap-menyuap adalah kejahatan korupsi. Beberapa peraturan perundang-undangan yang terkait dengan suapmenyuap merumuskan perbuatan itu sebagai tindak pidana suap saja, misalnya suap yang menyangkut kepentingan umum, baik aktif maupun pasif, seperti diatur dalam UU No 11 Tahun 1980. Suap terhadap pejabat bank yang diatur dalam UU No 10 Tahun 1998 dan suap dalam kaitan dengan pemilihan umum dan pemilihan kepala daerah (money politics), yang dalam praktik penegakan hukum tindak-tindak pidana suap ini kurang terangkat ke permukaan, karena jarang digunakan penegak hukum sekalipun perbuatan suap-menyuap semacam itu marak terjadi di masyarakat. ${ }^{67}$

67. Eddy Rifai, Artikel Dosen,Suap sebagai kejahatan Korupsi, Diterbitkan November 25, 
Suap diatur dalam: 68

1. Kitab Undang-Undang Hukum Pidana (Wetboek van Strafrecht, Staatsblad 1915 No 73)

2. UU No. 11 Tahun 1980 tentang Tindak Pidana Suap (“UU 11/1980”)

3. UU No. 20 Tahun 2001 tentang Perubahan UU No. 31 Tahun 1999 tentang Pemberantasan Tindak Pidana Korupsi serta diatur pula dalam UU No. 30 Tahun 2002 tentang Komisi Pemberantasan Korupsi ("UU Pemberantasan Tipikor")

\section{Tujuan Hukuman Bagi Pelaku Risywah}

Tujuan Hukuman dalam Hukum positif ini, telah mengalami beberapa fase, yaitu : ${ }^{69}$ Fase balasan perseorangan (vengeance-privee), Fase balasan Tuhan (veageance divini), atau balasan umum, atau penebusan (vengeance-publique), Fase Kemanusiaan (Humanitaire), Fase Keilmuan (scientique).

Fase balasan perseorangan, bahwa hukuman tersebut berada di tangan seseorang (sikorban atau walinya) yang bertindak atas dasar perasaan hendak menjaga diri mereka dari penyerang dan atas dasar naluri hendak membalas terhadap orang yang menyerangnya. Oleh karena itu balasan itu tidak ada batasnya, kadang-kadang melebihi dari perbuatan sendiri bahkan kadangkadang bisa menimbulkan perang antar suku atau golongan. Fase balasan Tuhan, bahwa pembuat harus menebus kesalahannya dengan balasan umur agar pembuat merasa kapok dan orang lain tidak menirunya. Pada fase kemanusiaan, bahwa prinsip-prinsip keadilan dan kasih sayang dalam mendidik dan memperbaiki diri pembuat telah mulai dipakai, pada fase tersebut lahir teori kontrak sosial yang menyatakan, bahwa perseorangan terlepas dari kekuasaan negara, kecuali sebagian kecil saja dari kemerdekaan itu hanya diberikan kepada masyarakat, yaitu ketika bercampur dengannya.

Dari keterangan-keterangan fase tersebut di atas ternyata tujuan hukuman itu selalu berbeda dan mengalami perubahan mendasar. Dan mereka menitik beratkan pada akal pikiran semata. Dengan demikian tujuan

68. http://consultanonline.wordpress.com/tahukah-kamu/kejahatan-pidana/beda-suapdan-gratifikasi

${ }^{69}$. Ahmad Hanafi,Asas-asas Hukum Pidana Islam,Jakarta:PT Bulan Bintang,1990,hlm.257 
hukuman yang diterapkan tidak mutlak dan selalu mencari alternatif hukum yang lain yang lebih efektif yang bisa diterapkan.

Dalam fase keilmuan muncul beberapa pikiran, yaitu, hukuman itu mempunyai tugas dan tujuan ilmiah, yakni melindungi masyarakat dari perbuatan-perbuatan asusila dengan mencegah seseorang pembuat untuk tidak mengulangi lagi (preventionspescile) dan mencegah orang lain untuk tidak mengikuti (prevention general). Jadi penjatuhan hukuman pada masa sekarang adalah keadilan dan melindungi masyarakat. Rasa keadilan menghendaki agar suatu hukuman harus sesuai dengan perbuatannya. Inilah tindakan pemeliharaan dan pengamanan. Dasar tersebut mempunyai dua fungsi, yaitu: Pertama, fungsi moral, untuk mewujudkan pemuasan perasaan orang banyak dalam menjamin rasa ketentraman dalam masyarakat. Kedua, fungsi sosial, untuk mewujudkan adanya usaha pencegahan terhadap perbuatan suap-menyuap tersebut.

Dari uraian di atas kita dapat menarik kesimpulan beberapa catatan bahwa segala tindak kejahatan dan perbuatan-perbuatan asusila akan selalu meresahkan masyarakat dan selalu akan membuat masyarakat tidak merasa tentram. Oleh karena itu, segala tindakan yang melanggar norma dan aturan hukum akan selalu mendapatkan balasan dari pihak yang berwewenang melalui hukum-hukum yang berlaku.

\section{Sanksi Hukuman Bagi Penyuap dan Penerima Suap}

4. Undang-undang Tindak Pidana Suap No 11 Tahun 1980

Pidana penjara selama-lamanya 3 (tiga) tahun atau denda sebanyakbanyaknya Rp.15.000.000.- (lima belas juta rupiah) (Pasal 3 UU 3/1980).

2. KUHP:

Pidana penjara paling lama sembilan bulan atau pidana denda paling banyak tiga ratus rupiah. ${ }^{70}$

3. UU Pemberantasan Tipikor:

Dipidana dengan pidana penjara paling singkat 1 (satu) tahun dan paling lama 5 (lima) tahun dan atau pidana denda paling sedikit Rp

\footnotetext{
70. Moeljatno,Kitab Undang-undang Hukum Pidana,Jakarta: PT Bumi Aksara,2009,hlm.57
} 
50.000.000,00 (lima puluh juta rupiah) dan paling banyak Rp 250.000.000,00 (dua ratus lima puluh juta rupiah) pegawai negeri atau penyelenggara negara yang menerima hadiah atau janji padahal diketahui atau patut diduga, bahwa hadiah atau janji tersebut diberikan karena kekuasaan atau kewenangan yang berhubungan dengan jabatannya, atau yang menurut pikiran orang yang memberikan hadiah atau janji tersebut ada hubungan dengan jabatannya. ${ }^{71}$ (Pasal 11 UU Pemberantasan Tipikor).

\section{Pelaksanaan Hukuman dan Eksistensinya}

Indonesia merupakan Negara Hukum yang berdasarkan pancasila dan Undang-undang Dasar 1945, yang penduduknya manyoritas beragama Islam serta aturan untuk menjalankan syari'atnya diatur didalam pasal 29 UUD 45. Oleh karena itu Indonesia bukan negara Islam tetapi negara demokrasi yang berazaskan pancasila, dimana pemerintah mempunyai kekuasaan dan wewenang dalam melaksanakan berbagai macam kebijaksanaan, termasuk kewenangan Hukum/Hukuman. Jadi pemerintah mempunyai kewenangan mutlak dalam menjalankan hukuman baik yang mengenai individu maupun secara keseluruhan mendapat perlakuan yang sama dihadapan pemerintah, dalam hal ini adalah lembaga peradilan Indonesia.

Dengan demikian Hukum yang diatur oleh pemerintah untuk rakyatnya, baik keperdataan maupun Hukum Pidana keberlakuannya harus dapat dilaksanakan (yuridis formil) artinya bila ada yang melanggar atau tidak mematuhi hukum-hukum tersebut akan dikenakan sanksi yang sesuai dengan ketentuan Hukum yang berlaku, kecuali hukum berkenaan muslim yaitu keperdataan dipegang oleh departemen agama (Depag) atau peradilan agama.

Adapun lainnya dipegang oleh lembaga pengadilan Negeri ( Umum ), sehingga keberadaan Hukum tersebut keberlakuannya bersifat yuridis formil, berlaku untuk semua warga Indonesia.

Kemudian mengenai hukum posotif terhadap tindak pidana suap merupakan suatu bentuk kejahatan Asusila yang dapat meresahkan masyarakat banyak dan menganggu ketertiban umum. Pelaksanaan hukuman bagi tersangka tindak pidana tersebut adalah kewenangan pengadilan negeri,

71. Tim Penyusun Undang-undang R.I.Nomor 46 tahun 2009 tentang Pengadilan Tipikor, Bandung: Citra Umbara,hlm.36 
karena eksistensi Hukum penyuapan itu bersifat yuridis formil, dan semua tindak pidana menjadi kewenangannya. Bagi mereka yang terbukti melakukan kejahatan tersebut akan dikenakan sanksi berdasarkan pasal-pasal tersebut.

Sedangkan mengenai pelaksanaan hukuman tersebut setelah adanya penyelidikan-penyelidikan yang intensif dan adanya bukti-bukti yang menguatkan terjadinya perbuatan tersebut, Hukuman-hukuman yang tercantum dalam pasal-pasal terhadap pelanggaran Asusila itu adalah seperangkat hukum yang ada di Indonesia sebagai warisan kolonial Belanda yang berlaku hingga sekarang, yang konon telah mengalami pembaharuanpembaharuan dalam pelaksanaan hukuman tersebut.

Hukuman yang dikenakan padanya adalah penjara. Penjara adalah tempat orang yang memperbaiki narapidana ( NAPI ). Dengan masuknya Napi kedalam penjara maka di dalam penjara Napi tidak perlu dipidana lagi. Dengan demikian sistem hukum penjara yang berlaku sekarang tidak efektif dan tidak berhasil mengenai sasaran yang diinginkan, walau sistem kepenjaraan yang ada di Indonesia itu selalu mengalami perubahan. Memang pelaksanaan hukuman itu berjalan dan dilaksanakan oleh aparat yang berwenang, tapi tidak menghasilkan apa yang diinginkan oleh masyarakat. Ini terbukti dengan banyaknya kasus suap yang terdaftar di komisi pemberantas korupsi (KPK), Dan penjara buat mereka dijadikan sebagai pengalaman yang menghasilkan, yang membawa pengaruh pada dirinya yang secara kuantitas lebih berani, sehingga masyarakat menjadi takut melihat penjahat yang keluar masuk penjara.

Hal ini memberikan peluang bagi pelaku kejahatan untuk beraksi lebih keras dan berani lagi. Mereka mengatakan " kalau seorang penjahat belum merasakan penjara, itu dikatakan atau dianggap kecil dan tidak ada bisanya. Oleh karena itu aparat yang berwenang harus mencari langkah-langkah baru untuk betul-betul mengantisipasi tindak-tindak pidana penyuapan, agar pelaku kejahatan tersebut takut dan jera sehingga tidak mengulangi lagi dan para pelaku merasa ngeri melakukan perbuatan tersebut.

\section{Istilah yang berkaitan dengan suap}

\section{a. Gratifikasi}

Gratifikasi adalah, Pemberian dalam arti luas, yakni meliputi pemberian uang, barang, rabat (discount), komisi, pinjaman tanpa bunga, tiket 
perjalanan, fasilitas penginapan, perjalanan wisata, pengobatan cuma-cuma, dan fasilitas lainnya. Gratifikasi tersebut baik yang diterima di dalam negeri maupun di luar negeri dan yang dilakukan dengan menggunakan sarana elektronik atau tanpa sarana elektronik. ${ }^{72}$

Di dalam buku Buku Saku Memahami Gratifikasi yang diterbitkan Komisi Pemberantasan Korupsi (KPK) dijelaskan contoh-contoh pemberian yang dapat dikategorikan sebagai gratifikasi yang sering terjadi, yaitu: ${ }^{73}$

1. Pemberian hadiah atau parsel kepada pejabat pada saat hari raya keagamaan, oleh rekanan atau bawahannya.

2. Hadiah atau sumbangan pada saat perkawinan anak dari pejabat oleh rekanan kantor pejabat tersebut

3. Pemberian tiket perjalanan kepada pejabat atau keluarganya untuk keperluan pribadi secara cuma-Cuma

4. Pemberian potongan harga khusus bagi pejabat untuk pembelian barang dari rekanan

5. Pemberian biaya atau ongkos naik haji dari rekanan kepada pejabat

6. Pemberian hadiah ulang tahun atau pada acara-acara pribadi lainnya dari rekanan

7. Pemberian hadiah atau souvenir kepada pejabat pada saat kunjungan kerja

8. Pemberian hadiah atau uang sebagai ucapan terima kasih karena telah dibantu.

\section{Analisis Dan Perbandingan}

\section{Pengertian Risywah.}

Menurut UU Tindak Pidana Suap No. 11 tahun 1980: " Suap di definisikan sebagai memberi atau menjanjikan sesuatu kepada seseorang dengan maksud untuk membujuk supaya orang itu berbuat sesuatu atau

\footnotetext{
72. Undang-undang Tipikor, penjelasan pasal 12B,hlm.50

73. http://consultanonline.wordpress.com/tahukah-kamu/kejahatan-pidana/beda-suapdan-gratifikasi.
} 
tidak berbuat sesuatu dalam tugasnya, yang berlawanan dengan kewenangan atau kewajibannya yang menyangkut kepentingan umum."

Menurut Hukum Islam: Risywah adalah pemberian yang diberikan oleh seorang kepada orang lain (pejabat) dengan maksud meluluskan suatu perbuatan yang batil (tidak benar menurut syari'ah) atau membatilkan perbuatan yang hak.

\section{Landasan Risywah.}

Menurut Hukum di Indonesia Suap di atur dalam : Kitab UndangUndang Hukum Pidana (Wetboek van Strafrecht, Staatsblad 1915 No 73), UU No. 11 Tahun 1980 tentang Tindak Pidana Suap (“UU 11/1980”), UU No. 20 Tahun 2001 tentang Perubahan UU No. 31 Tahun 1999 tentang Pemberantasan Tindak Pidana Korupsi serta diatur pula dalam UU No. 30 Tahun 2002 tentang Komisi Pemberantasan Korupsi ("UU Pemberantasan Tipikor")

Menurut Hukum Islam perkara suap di jelaskan dalam : al-Qur'an, alHadits dan Ijma' Ulama

\section{Pembuktian Suap Atau Gratifikasi}

Menurut Undang-undang R.I. nomor 46 tahun 2009 tentang Pengadilan Tindak Pidana Korupsi ( TIPIKOR ) pasal 12B disebutkan;

1. setiap gratifikasi kepada pegawai negeri atau penyelenggara negara dianggap pemberian suap, apabila berhubungan dengan jabatannya dan yang berlawanan dengan kewajibannya atau tugasnya, dengan ketentuan sebagai berikut:

a. Yang nilainya Rp.10.000.000,00 ( sepuluh juta rupiah ) atau lebih, pembuktian bahwa gratifikasi tersebut bukan merupakan suap dilakukan oleh penerima gratifikasi.

b. Yang nilainya kurang dari Rp.10.000.000,00 ( sepuluh juta rupiah ), pembuktian bahwa gratifikasi tersebut suap dilakukan oleh penuntut umum.

Kemudian di sebutkan dalam pasal 12C Poin 1, ketentuan sebagaimana dimaksud dalam pasal $12 \mathrm{~B}$ ayat 1 tidak berlaku, jika penerima melaporkan gratifikasi yang diterimanya kepada Komisi Pemberantasan 
Tindak Pidana Korupsi, paling lambat 30 hari kerja terhitung sejak tanggal gratifikasi tersebut diterima.

Menurut Hukum Islam, bukti yang paling kuat adalah dengan pengakuan dari pelaku itu sendiri, kalau memang tidak, dengan ada saksi yang adil dan bukti-bukti yang akurat.

\section{Hukuman Bagi Penyuap Dan Penerima Suap}

Menurut Undang-undang Tindak Pidana Suap No 11 Tahun 1980, yang memberi di Pidana penjara selama-lamanya 5 (lima) tahun atau denda sebanyak-banyaknya Rp.15.000.000.- (lima belas juta rupiah) (Pasal 3 UU 3/1980). Sedangkan yang menerima suap di Pidana penjara selama-lamanya 3 (tiga) tahun atau denda sebanyak-banyaknya Rp. 15.000.000,- ( lima belas juta rupiah ).

Menurut hukum Islam, Mengenai tindak pidana Suap-menyuap dalam Al Qur'an dan hadits tidak disebutkan sanksi hukumanya, Maka para Fuqaha menjelaskan tindak pidana suap dikenai sanksi $t a^{\prime} z i r$ berdasarkan kemaslahatan sedang pelaksanaanya diserahkan dalam ijtihad para hakim. Sayyid Sabiq menyebutkan dalam kita Fikih Sunnah :

a. Ta'zir bisa dilakukan dengan perkataan, seperti kecaman, teguran, dan nasehat,

b. Ta'zir bisa dilakukan dengan perbuatan sesuai dengan tuntutan keadaan. Sebagaimana ta'zir dapat dilakukan dengan cambukan, penahanan, pemborgolan, pengasingan, pengucilan dan hukuman mati.

Sebetulnya hukuman $t a^{\prime} z i r$ bertujuan memberi pengajaran dan mendidik serta mencegah orang lain melakukan perbuatan serupa. Hal ini sebagaimana dikemukakan oleh Abdurrahman Al-Jaziri:

"Adapun ta'zir adalah pengajaran atau pendidikan berdasarkan ijtihad hakim dengan maksud mencegah perbuatan yang diharamkan supaya tidak mengulangi perbuatan tersebut maka setiap orang yang melakukan perbuatan yang diharamkan dan tidak mempunyai had, qisas, kafarat. Bagi hakim diberi kebebasan menghukum dengan ta'zir berdasarkan ijtihadnya 
yang sekiranya dapat mencegah kepadanya untuk mengulangi perbuatannya yang dipikul atau dipenjarakan dan diberi penghinaan ringan". ${ }^{74}$

Di dalam tulisan ini yang menjadi titik perbedaan mendasar tentang suap antara hukum Islam dan UU Tindak pidana suap No.11 tahun 1980 adalah sanksi hukuman terhadap pelaku risywah. Sanksi yang ditetapkan di Indonesia tidak memberi efek jera sama sekali Sehingga, Risywah hari ini merupakan jarimatul 'aamah atau kejahatan publik yang telah membudaya dan biasa di negeri ini. Membudaya karena menjadi suatu hal yang seolah melekat kuat disetiap lini kehidupan masyarakat dari kelas pejabat sampai kelas rakyat. Dan menjadi biasa karena lumrah dilakukan dan diketahui masyarakat tanpa tedeng aling-aling.

Banyak orang yang tidak peduli melakukan risywah dalam transaksi, pekerjaan bahkan dalam hukum demi kepentingan pribadi atau kelompok. Mereka berasumsi hal tersebut sah-sah saja bahkan dianggap sebagai rizqi yang halal untuk dinikmati. Hari ini orang pun bisa kebal hukum karena uang suap yang menyumpal mulut para hakim yang doyan dengan harta haram.

Bahkan Budaya KKN di negeri ini menjadi subur karena ditopang dengan budaya suap-menyuap/risywah yang telah mengakar kuat. Kita lihat mulai dari tingkat pejabat tinggi sampai tingkat RT dan RW melakukan suap. Memang parah sistem birokrasi di negeri ini karena terlanjur di pernuhi dengan risywah.

Dari fakta-fakta yang sudah terungkap mengenai kasus suap-menyuap sepatutnya Indonesia menetapkan hukuman berat bagi pelaku suap yaitu 20 tahun penjara, hukuman seumur hidup atau hukuman mati. Sebagaimana Di Indonesia terdapat Undang-undang Nomor 31 tahun 1999 yang mengatur pemberantasan tindak pidana korupsi. Disana dijelaskan dalam ketentuan pidananya lebih komprehensif artinya menyangkut semua kelompok atau korporasi terutama pasal yang mengatur ketentuan pidananya adalah Pasal 2.

Dalam ayat pertama disebutkan tentang perbuatan melawan hukum melakukan perbuatan memperkaya diri sendiri maupun orang lain maupun korporasi yang dapat merugikan keuangan atau perekonomian negara bagi Pegawai Negeri maupun Penyelenggara Negara disebutkan dalam pasal yang lain yaitu disertai dengan penyalahgunaan kekuasaan atau kewenangan.

74. Abdurrahman al Jaziri, Kitab Al Figh 'ala Mazahib al Arba'ah, (Beirut-Libanon: Dar al Kutub al Ilmiyah, t.th.,) 397 
Dan pelakunya dapat dijerat dengan hukuman yang berat (maksimal) yaitu penjara seumur hidup ataupun hukuman mati. Penguasa negara tidak tunduk kepada satu jenis hukuman dan menitik beratkan pada pencapaian tujuan maslahat hak dan keadilan. Dalam hal ini pemerintah mempunyai wewenang untuk menjadi peraturan perundang-undangan dan kewajiban kita terhadap pemerintah selama tidak diperintahkan dalam hal kema'siatan. Dalam Al Qur'an disebutkan Q.S. aN-Nisa'59:

"Hai orang-orang yang beriman taatilah Allah dan taati Rasul-Nya dan (Ulil al-Amri) dari kamu. Maka jika kamu berselisih tentang sesuatu maka kembalikanlah kepada dia kepada Allah dan Rasul-Nya, jika kamu beriman kepada Allah dan hari kemudian. Itu adalah kebaikan dan penyelesaian sebaik-baiknya.

Adapun solusi yang tepat bagi para penyuap dan penerima suap adalah hukuman mati, karena dia telah memperkaya diri sendiri maupun orang lain, dapat merugikan keuangan atau perekonomian negara bagi Pegawai Negeri, penyalahgunaan kekuasaan atau kewenangan.

Ganjaran hukuman mati itu, merupakan langkah yang dinilai paling tepat diterapkan bagi penyuap dan penerima suap yang ada di negeri ini, Sebab tanpa diterapkannya hukuman mati terhadap penyuap dan penerima suap di negeri tercinta ini, pelaku kejahatan akan terus berkembang semakin subur dan tidak akan pernah berhenti. Jadi, perlu adanya ketegasan dalam menerapkan hukuman mati terhadap penyuap dan penerima suap yang telah menghancurkan sendi-sendi kehidupan perekonomian negara.

Penerapan hukuman mati itu juga diatur dalam ketentuan hukum di Indonesia, namun sampai saat ini tidak pernah dilaksanakan terhadap pelaku kejahatan negara yang nyata-nyata telah merugikan keuangan negara. Oleh karena itu, pemerintah juga perlu mengkaji ulang Undang-Undang yang menerapkan hukuman mati tersebut. Selama ini, pelaku yang terbukti suap itu, hanya dijatuhi hukuman lima tahun penjara atau lebih.

Ini dinilai terlalu ringan, dan tidak membuat efek jera terhadap mereka yang telah memperkaya diri sendiri atau dengan sengaja menyalahgunakan keuangan negara. dengan penerapan hukuman mati terhadap pelaku suapmenyuap itu, diyakini dapat membuat rasa takut atau kehilangan nyali para perusak bangsa, serta mereka tidak akan mengulangi lagi kejahatan tersebut.

Penerapan hukuman mati itu, juga salah satu solusi untuk menyelamatkan keuangan negara dari penyuap dan penerima suap yang 
juga sebagai musuh negara. Perlunya penerapan hukuman mati bagi penyuap itu, untuk terciptanya penegakan hukum tegas dan benar, sehingga minat untuk melakukan penyimpangan keuangan negara semakin berkurang.

Hukuman lima tahun penjara terhadap pelaku penyuapan tersebut, jelas membuat senang bagi mereka yang melanggar hukum tersebut. Karena, pelaku yang menjalani hukuman di Lembaga Pemasyarakatan (Lapas) itu, juga akan memperoleh remisi atau pengurangan hukuman. Penyuap tersebut juga tidak akan penuh menjalani hukuman di Lapas. Pemerintah juga perlu ketegasan mengenai penerapan hukuman terhadap penyuap dan penerima suap itu, yakni apakah hukuman 20 tahun penjara, hukuman seumur hidup atau hukuman mati.

\section{Penutup}

Risywah (sogok/suap) adalah sesuatu (harta) yang diberikan kepada seseorang dengan tujuan untuk mendapatkan sesuatu yang diinginkan dengan cara yang batil. Atau sesuatu yang diberikan kepada seseorang yang memiliki kebijakan, baik dalam rangka memenangkan suatu kebatilan atau menghalangi suatu yang benar. Risywah dalam pandangan hukum Islam adalah haram berdasarkan dalil al Qur'an , as Sunnah dan Ijma' ulama

Suap di dalam Undang-undang tindak pidana no 11 tahun 1980, definisikan sebagai memberi atau menjanjikan sesuatu kepada seseorang dengan maksud untuk membujuk supaya orang itu berbuat sesuatu atau tidak berbuat sesuatu dalam tugasnya, yang berlawanan dengan kewenangan atau kewajibannya yang menyangkut kepentingan umum. Dalam hal pemberian hukuman bagi para penyuap menurut hukum Islam dan hukum positif, maka terdapat kesamaan dan perbedaan dalam tujuan yang diinginkan oleh kedua hukum tersebut, yaitu: Persamaannya; a. Peringatan dan pendidikan, b. Memperbaiki moralitas manusia, c. Pencegahan, d. Menegakkan keadilan dan ketertiban, e. Memelihara melindungi hak dan kewajiban tiap individu.

Adapun perbedaan dari kedua hukum tersebut dalam tujuan yang ingin dicapai dan eksistensinya adalah sebagai berikut:

Pertama; Hukum Pidana Islam; a. Sumber / Konsep hukumnya adalah AlQur'an dan Al-Hadits, b. Arti dari hukum itu sendiri adalah menakutkan, c. Hukuman adalah sebagai balasan dan siksaan dari Allah SWT, d. Hukuman 
diberikan kepada orang dewasa, sedang pada anak-anak ( anak kecil ) bukan hukuman melainkan pelajaran, e. Hukuman adalah sebagai penghinaan didunia dan di akhirat akan disiksa.

Ini semua karena dalam hukum Islam ( Pidana Islam ) tindak pidana kejahatan erat hubungannnya dengan agama dan karena Islam mengatur perilaku manusia pada umumnya dan khususnya mengatur perbuatan mukallaf yang dapat dipertanggungjawabkan serta perbuatan-perbuatan manusia itu merupakan tindak pidana yang oleh karenanya dikenakan sanksi demi untuk kemaslahatan masyarakat luas baik didunia maupun diakhirat kelak.

Kedua, Hukum Positif; a. Sumber-sumber hukumnya dari pancasila dan UUD' 45, b. Hukuman yang berlaku tidak menakutkan, malah membuat pelaku semakin nekad untuk mengulangi perbuatannya, c. Penjara bukan sebagai balasan dan siksaan tetapi merupakan sarana rehabilitas dan pembinaan para Narapidana (NAPI), d. Penjara bukanlah sebagai tempat penghinaan tetapi tak ubahnya sebagai tempat peristirahatan para narapidana. Pada kesimpulannya hukum positif adalah hukum yang berlaku di Indonesia untuk semua ras, agama dan suku.

\section{Pustaka Acuan}

A'sqolani, Ibnu Hajar, Fathul Bari, Beirut: Dar Al Ma'rifah, 1379.

Abdullah Ath-Thawil, Muhammad, Kapan Hadiah=Suap, Surabaya: Pustaka Yassir,2010.

Abdullah Bin Abd. Muhsin, Suap Dalam Pandangan Islam, Jakarta:Gema Insani Press,2001.

Abdurrahman Al Jaziri, Kitab Al Figh 'Ala Mazahib Al Arba'ah, Beirut: Dar Al Kutub Al Ilmiyah.

Abdurrahman Al-Gharyani, As-Shadiq, Fatwa-Fatwa Muamalah Kontemporer,Surabaya: Pustaka Progressif, 2004.

Abu 'Abdillah, Muhammad Bin Ismail, Shihih Bukhari, Versi Maktabah Syamilah.

An-Nablusi, Abdul Ghani Bin Ismail, Hukumsuapdanhadiah, Jakarta: Maktabah Al-Qur'an, 2003. 
Bahgia

Aziz Dahlan, Abdul, Ensiklopedi Hukum Islam, Jakarta: Ichtiar Baru Van Hoeve, 1996.

Bin Hambal, Ahmad Bin Muhammad, Musnad Imam Ahmad Hambal (Tahqiq Syu'aib Arnauth Dkk), Muasasah Al Risalah, 2001.

Bin 'Abdurrahman, Khalid, Al-Fataawa Al-Syariyyah Fi Al-Masaail Al'Ashriyyah, Riyadh : Lajnah Daimah Lil Buhuts Al-Ilmiyyah Wal Ifta',1420.

Bin Hanbal, Ahmad Bin Muhammad. Musnad Imam Ahmad, Muassasah AlRisalah, Versi Maktabah Syamilah.

Erwanditarmizi, Harta Haram Muamalat Kontemporer, Bogor : P.T. Berkat Muliainsani, 2013.

Hanafi, Ahmad, Asas-Asas Hukum Pidana Islam, Jakarta: PT Bulan Bintang,1990.

Hawa, Saiid, Al-Asaasu Fi Tafsir,Mesir: Dar As-Salam, 1405.

Husain Jauhar, Ahmad Al-Mursi, Maqasid Syariah,Jakarta:Amzah,2009.

Ibn Abdul Muhsin, Abdullah, Suap Dalam Pandangan Islam ( Judul Asli: Jarimah Al-Risywah Fiy Syari'ah Al-Islâmiya), Penerjemah: Muchotob Hamzah Dan Subakir Saerozi, Jakarta: Gema Insani Press, 2001.

Ibn Al-Hasan Al-Thabrusi, Abu Ali Al-Fadhl, Majma' Al-Bayan Fi Tafsir AlQur'an, Beirut: Dar Al-Kutub Al-Ilmiyah, 1997.

Ibn Ali Al-Syaukani, Muhammad, Tafsir Fathul Qadir, Kairo: Dar Al-Hadits, 2003.

Ibn Jarir Al-Thabari, Abu Ja'far Muhammad, Tafsir Al-Thabari; Al-Musamma Bi Jami' Al-Bayan Fi Ta'wili Al-Qur'an, Beirut: Dar Al-Kutub Al-Ilmiyah, 1999.

Ibnu Katsir,Tafsir Al-Qur'an Al-'Adhim, Mamlakah Suudiyah: Dar Al-Kunuz Isybiliya, 1430.

Ibnu Mandzur ,Lisanul 'Arob, Beirut: Dar Al Shodir.

Ibnu Qudamah, Al Mughni, Darul Fikr, Beirut, 1984.

Ichtiar Baru Van Hoeve, Ensiklopedi Hukum Islam. 
Isa At Tirmidzi, Muhammad, Sunan At Tirmidzi, Beirut: Dar Al Kutub Al Ilmiyah, 2003.

Junaidil, Hamd Bin Abdurrohman Atsaru Risywah Fi Ta'tsuri Namwi Al Iqtishodi Wa Asalib Daf 'Tha Fi Dzilli Syariah Islamiah, Riyadh: Al Markas Al Arobi Li Dirosah Al Amniyyah Wa Tadrib, 1982.

Muhammad Bin Abdulloh Al Hakim ,Mustadrok 'Ala Sohihain, Tahqiq Musthofa Abdul Qodir 'Atho, Beirut: Dar Al Kutub Al Ilmiah, 1990.

Muhammad Bin Abi 'Abbasar Romli, Syamsudin, Nihayatul Muhtaj, Beirut: Dar Al Fikr, 1984.

Mustafa, Ibrahim, Al-Mu'jam Al-Wasith, Istanbul: Al-Maktabah AlIslamiyah,1972.

Musthofa, Ibrohim, Dkk, Al Mu'jam Al Wasith, Daru Al Dakwah.

Mutawalli Al-Sya'rawi, Muhammad, Tafsir Al-Sya'rawi, Kairo: Akhbar AlYaum, 1991.

Nasir As-Sa'di, Abdurrahman, Tafsir Karim Ar-Rahman, Al-Maktabah AsySyamilah.

Praja, Juhaya S., Filsafat Hukum Islam, Bandung: LPM Universitas Islam Bandung, 1995.

Qardhawi, Yusuf, Halal Dan Haram Dalam Islam, Jakarta: Gema Insani Press,2001.

Qurtubi , Al Jami' Li Ahkamil Qur'an, Mesir: Dar Al Hadits, 1423.

Rifai, Eddy, Artikel Dosen,Suap Sebagai Kejahatan Korupsi, 2010.

Sabiq, Sayyid, Fikih Sunnah, Jakarta: Dar Fath Lil 'Alami Al-Arabiy,2009.

Syahatah, Husain, Suap Dan Korupsi Dalam Perspektif Syari'ah, Jakarta: Ahmzah, 2008.

Syaukani, Muhammad Ibn Ali Ibn Muhammad, Nailul Author Min Ahadits Sayyid Al Akhbar Syarh Muntaqo Al Akhbar,Mesir: Maktabah Dar AlTurats.

Thobari, Ibnu Jarir, Tafsir Al-Tabari Jamiul Bayaan Fi Ta'wil Al Qur'an, Beirut: Dar Al Kutub Al Ilmiyyah, 1420. 